U.S. DEPARTMENT OF THE INTERIOR

U.S. GEOLOGICAL SURVEY

\title{
INTERNAL STRUCTURE OF BARS IN GRAND CANYON, ARIZONA, AND EVALUATION OF PROPOSED FLOW ALTERNATIVES FOR GLEN CANYON DAM
}

by

\author{
${ }^{1}$ David M. Rubin, ${ }^{2}$ John C. Schmidt, ${ }^{1}$ Roberto A. Anima, ${ }^{1}$ Kristin M. Brown, \\ ${ }^{1}$ Ralph E. Hunter, ${ }^{3}$ Hiroshi Ikeda, ${ }^{1}$ Bruce E. Jaffe, ${ }^{4}$ Richard R. McDonald, \\ 4Jonathan M. Nelson, ${ }^{1}$ Tom E. Reiss, ${ }^{1}$ Rex Sanders, and ${ }^{1}$ Richard G. Stanley
}

Open-File Report OF94-594

Prepared in cooperation with the U.S. Bureau of Reclamation

This report is preliminary and has not been reviewed for conformity with U.S. Geological Survey editorial standards (or with the North American Stratigraphic Code). Any use of trade, product, or firm names is for descriptive purposes only and does not imply endorsement by the U.S. Government.

1U.S. Geological Survey, Menlo Park, CA 94025

2Department of Geography, Utah State University, Logan, UT, 84322

${ }^{3}$ ERC, University of Tsukuba, Tsukuba, Ibaraki 305, Japan

${ }^{4}$ U.S. Geological Survey, Denver, CO 80225 


\section{TABLE OF CONTENTS}

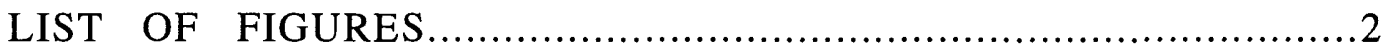

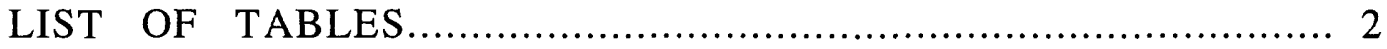

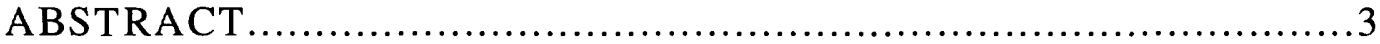

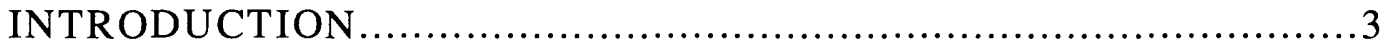

Objectives............................................................... 3

Overview............................................................... 4

METHODS .................................................................. 5

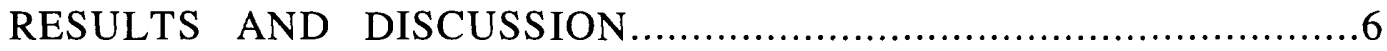

Depositional Processes and Sequences.......................................... 6

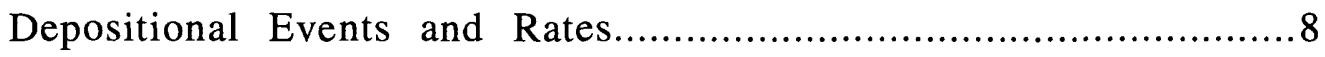

EVALUATION OF FLOW ALTERNATIVES.......................................10

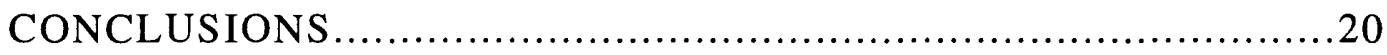

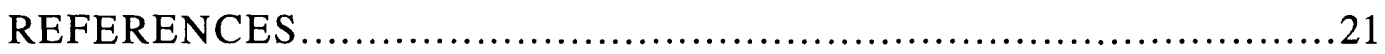

APPENDIX (OBSERVATIONS OF INTERNAL STRUCTURE).................22 


\section{LIST OF FIGURES}

Figure 1. Map of Colorado River downstream from Glen Canyon Dam.

Figure 2. Map showing flow patterns in a recirculation zone.

Figure 3. Schematic cross section illustrating the generalized internal structure and history of Grand Canyon reattachment bars.

Figure 4. Cumulative frequency plot for the year-round steady flow alternative.

Figure 5. Cumulative frequency plot for the seasonally adjusted steady flow alternative.

Figure 6. Cumulative frequency plot for the existing monthly volume steady flow alternative.

Figure 7. Cumulative frequency plot for the low fluctuating flow alternative.

Figure 8. Cumulative frequency plot for the moderate fluctuating flow alternative.

Figure 9. Cumulative frequency plot for the high fluctuating flow alternative.

Figure 10. Cumulative frequency plot for the no-action flow alternative.

Figure 11. Cumulative frequency plot for a pre-dam year (1957).

\section{LIST OF TABLES}

Table 1. Study sites.

Table 2. Thickness of deposits of flow events.

Table 3. Effects of proposed alternative flows on bar accessibility. 


\begin{abstract}
Channel expansions are sites of deposition in bedrock canyons and alluvial rivers. Within these areas, deposition is commonly focused at the separation point, reattachment point, eddy center, or along the shear surface that separates the recirculation zone from the downstream flow in the main channel. This study examined the internal structure of reattachment bars, separation bars, and natural levees along the Colorado River in Grand Canyon, Arizona. The recirculation deposits (separation and reattachment bars) are characterized by a rotary flow pattern that includes upstream flow. Flow patterns within channel expansions vary with discharge. Increases in discharge generally increase the length of the recirculation zone. Both the rotary flow pattern and lengthening of the recirculation zone have been documented from internal structures in the bars. The character of climbing-ripple structures in the bar deposits demonstrates that recirculating flows pulsate erratically; field and lab current-meter measurements have demonstrated that these erratic pulsations occur even when discharge in the main channel is steady.

Depositional processes and internal structures differ for the three kinds of bars that were studied. During a single flood, deposits of reattachment bars are thickest. Reattachment bars typically produce fining-upward sequences, because circulation over the bars eventually weakens as upward growth restricts flow from the main channel. Separation-bar flood deposits are relatively thinner and are characterized by transgressive deposits that are commonly dominated by wave-generated structures. Levee deposits originated where bankward-directed flow transported sand onto narrow floodplains along the channel. Flow behind the levees was relatively weak and was typically directed downstream.

Depositional rates were determined for a variety of sites by examining sedimentary structures in deposits that survived subsequent flows. During the large flood of 1983 (with a peak that approached 100,000 cfs), deposition on some bars exceeded several meters, corresponding to a depositional rate of a few tens of centimeters per day. During the weaker floods of 1984,1985 , and 1986-a total of approximately three months of flow that approached 50,000 cfs-deposition was limited to a few tens of centimeters, corresponding to a depositional rate of approximately $1 \mathrm{~cm}$ per day. During flows within the range of power-plant operations (not exceeding approximately 30,000 cfs), depositional rates range to approximately $5 \mathrm{~cm}$ per day. In all flows, the range of depositional rates can be expected to have varied considerably, from sites that experienced net erosion or nondeposition to sites that exceeded the observed rates.

Three kinds of effects must be considered when evaluating flow alternatives on camping beaches: submergence/emergence of bars, erosion/deposition of bars, and net sediment transport through the canyon. A relatively large annual fluctuation and small daily fluctuation allow deposition at high elevations for a short time and allow emergence through most of the year; low daily fluctuations allow camping on bars that otherwise would be inundated daily.
\end{abstract}

\title{
INTRODUCTION
}

\section{Objectives}

Sedimentary structures provide a natural record of depositional processes that are responsible for building sand bars. This project examined sedimentary structures of alluvial bars along the Colorado River in Grand Canyon (Figure 1) in order to identify the important depositional processes, estimate rates of deposition, and test hypotheses regarding changes in location of depositional sites as a function of river discharge. Results of this project have two applications. First, the results can be used directly to evaluate proposed alternative flows. Second, the results can be used to help guide and test other 


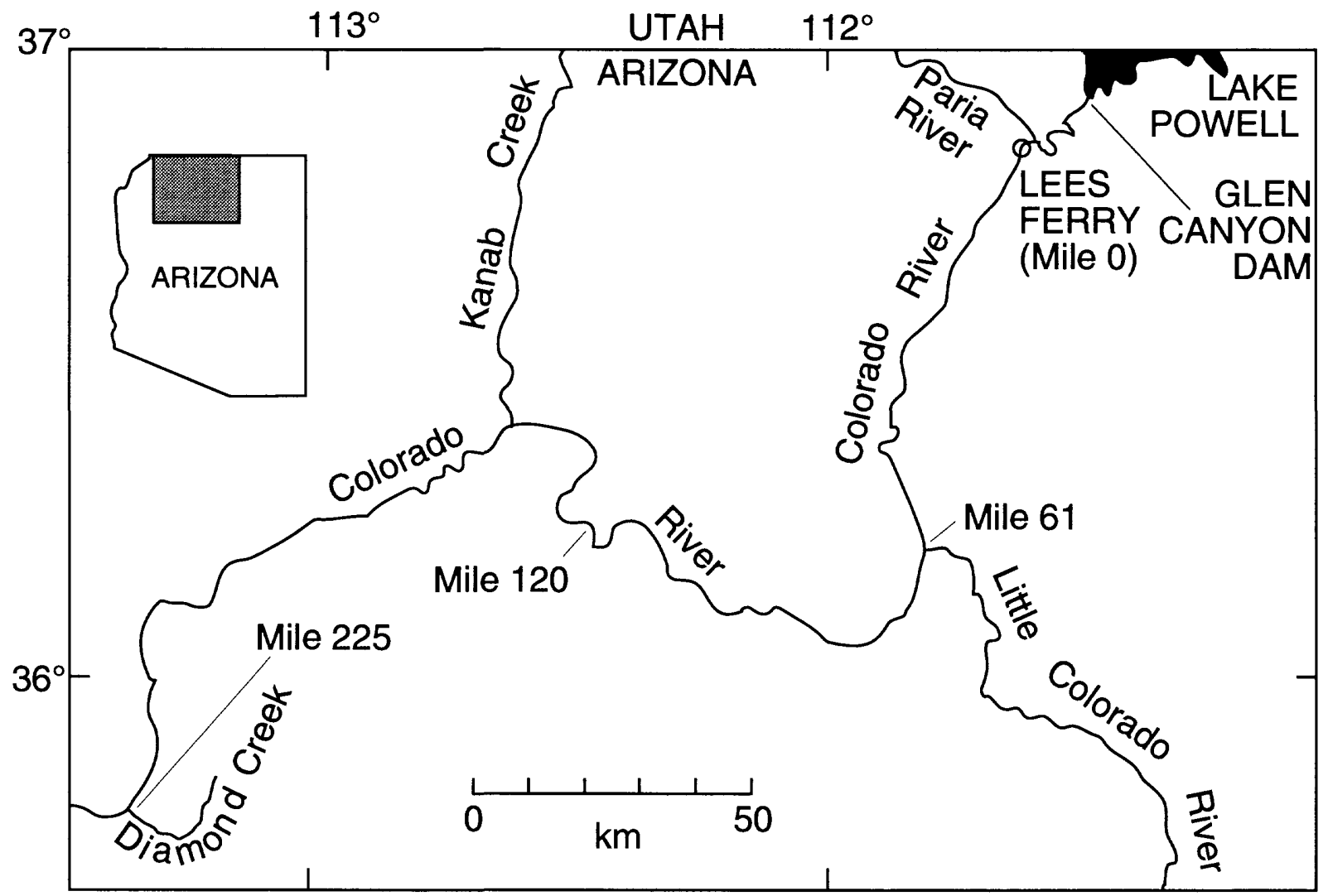

Figure 1. Map of Colorado River downstream from Glen Canyon Dam.

investigations, such as numerical modeling of deposition in recirculation zones. In this report, we briefly present findings of the stratigraphic investigations, and we evaluate some sedimentologic effects of the proposed flow alternatives.

\section{Overview}

Recirculation zones form in channel expansions where flow separates from and then reattaches to the bank (Figure 2). High-velocity flow from the constricted channel decelerates in the expansion and impinges on the bank at the reattachment point; sand is deposited in the expansion of the main channel and along the bank near the reattachment point. Velocities are also relatively low and deposition is induced near the center of the main recirculating current, and in secondary eddies and nearly stagnant flow that may be present immediately downstream from the separation point.

Flood deposits formed in low-velocity areas or in recirculating currents in bedrock gorges have been described throughout the western United States and in Australia (McKee, 1938; Howard and Dolan, 1981; Baker and others, 1983; Baker, 1984; Rubin, Schmidt, and Moore, 1990; Schmidt, 1990). Baker's studies have described "eddy bars" that form in the mouths of tributary canyons and downstream from bedrock spurs. In recirculation zones, deposition is localized near the separation point, reattachment point, eddy center, or along the "eddy line" (the shear surface that separates the recirculating eddy flow from the adjacent downstream flow in the main channel; this surface was called the separation 
surface by Rouse, Bhoota, and Hsu, 1951). Deposits that occur near the separation point have been termed "separation bars", and deposits that are centered at or are topographically highest at the reattachment point have been termed "reattachment bars"(Schmidt, 1990). Where subdivision is unnecessary or impossible, the composite bar can be termed an eddy bar, following Baker's usage. Recirculation zones and their deposits have also been described from point bars and concave benches in alluvial channels (Taylor, Crook, and Woodyer, 1971; Leeder and Bridges, 1975; Page and Nanson, 1982; Nanson and Page, 1983).

\section{METHODS}

Sedimentary structures were examined on river trips between 1985 and 1994. The most extensive trenching operations were conducted at the sites listed in Table 1. Internal structures were also examined at a larger number of small trenches, pits, and natural cut banks throughout the canyon.

Field methods consisted of digging trenches, mapping trench locations, and interpreting sedimentary structures exposed in the trenches. Trench locations and bar topography were mapped using infra-red electronic range and angle measurements; surveys were tied to existing benchmarks wherever possible. After sedimentary structures were measured and described, trenches were refilled, and the bar surface was smoothed.

Although interpretation of sedimentary structures is relatively straightforward, determining the age of specific strata is a more complicated procedure that relies on such evidence as photographs showing topographic change, comparison of vegetation visible in air photographs, the presence or absence of roots in deposits, and elevation of landward pinch-out of stratigraphic units (providing limits on river stage at time of deposition). Because such diagnostic background information is not always available, ages can not be determined at all sites. Where such information is available, a particular sequence of age determinations involves the kind of logic illustrated in the following example. A deposit that occurs at elevations inundated only by flows above 60,000 cfs (cubic feet per second), and that had not formed prior to 1980 , would be interpreted as having been deposited by the high flows of 1983. Deposits that overlie unconformities that are cut into this deposit and that extend onshore to an elevation corresponding to a river stage of approximately $50,000 \mathrm{cfs}$ would be interpreted as deposits of 1984-86 high-flow events. Stratigraphically higher deposits that pinch out at an elevation corresponding to the stage at $30,000 \mathrm{cfs}$ would be interpreted as post-1984-86 power-plant flows. In order to make age assignments using this technique, it is essential not only that there be background information for the site, but also that the bar include high-elevation regions that can be shown to have been deposited in 1983.

Stage-discharge relations were developed at most study sites in order to help establish elevations of inundation during high peak discharges that occurred in each year between 1983 and 1986. These relations were developed by surveying the elevation of the water surface at different times (see Schmidt and Graf, 1990, table 1, for times of 1985-1986 surveys) and estimating the discharge at the site. Discharge estimates were made in two ways: (1) at times of relatively steady discharge, hourly discharge data from the nearest U. S. Geological Survey gauging station was used in conjunction with U. S. Bureau of Reclamation routing data; and (2) at times of fluctuating discharge, water elevation of only the highest or lowest stage was surveyed and compared with the highest or lowest discharge, respectively, at the nearest gage. Although this method does not account for attenuation downstream from Lees Ferry, the relations were sufficiently accurate for the purposes of this study. 


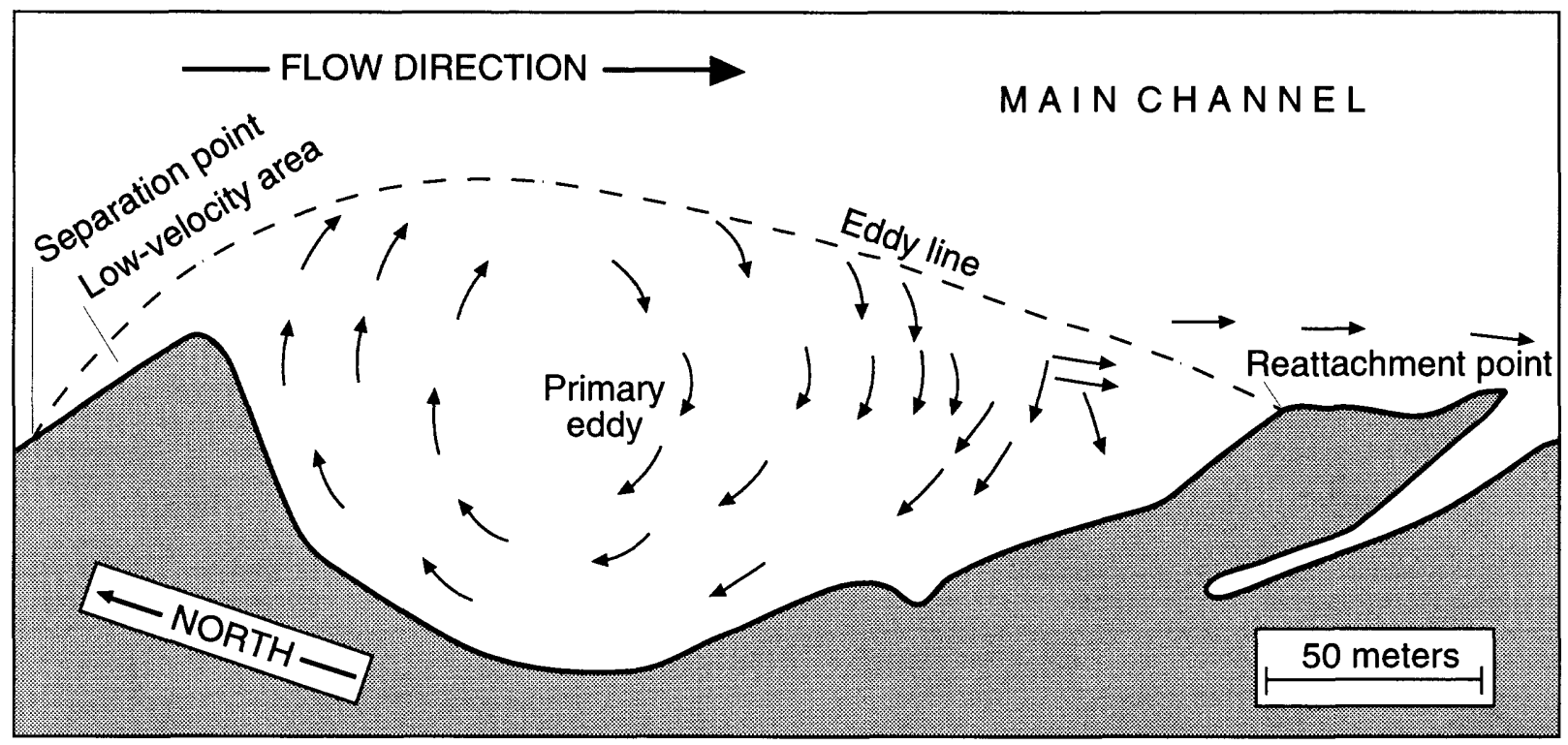

Figure 2. Map showing flow patterns in a recirculation zone. The site illustrated is 55-mile bar (from Rubin, Schmidt, and Moore, 1990).

\section{RESULTS AND DISCUSSION}

\section{Depositional Processes and Sequences}

Reattachment bars - Three kinds of bars have been examined (Figure 2 and APPENDIX): reattachment bars, separation bars, and levees. Depositional processes differ for the three kinds of bars. Flows that form reattachment bars are rotary in direction and vary from offshore and upstream (on upstream parts of the bars) to onshore and downstream (on downstream parts of the bars). Depositional processes and details of structures in reattachment bars have been published previously (Rubin, Schmidt, and Moore, 1990). Additional observations of sedimentary structures in this study have documented the downstream lengthening of the recirculation zone as discharge increases (from 5,000 cfs to $100,000 \mathrm{cfs}$ ), as has been reported from hydraulic observations (Schmidt and Graf, 1990; Schmidt, 1990).

A generalized depositional sequence for reattachment bars subjected to a flood begins with a basal scour surface overlain by basal deposits of relatively coarse sand. In the vicinity of the reattachment point, flow is commonly too turbulent for dunes to exist, and the basal unit is deposited rapidly and unstratified. This facies grades laterally (upstream and downstream) into beds deposited by fluvial dunes migrating away from the reattachment point. Circulation over the bar eventually shallows and weakens, either because continued growth causes the bar to restrict flow from the main channel or because river stage drops. As a result of the reduced flow over the bar, the size of sediment in transport decreases, and ripples replace dunes as the dominant bedform. This generalized depositional sequence describes most of the reattachment bars studied, although not all bars display the complete sequence. If deposition continues, flow over the bar surface may become so restricted that only mud is transported. Veneers of fine-grained sediment cover a number of bars in large expansions with low-velocity flow (for example, 55-mile bar); such fine-grained veneers appear to be readily colonized by vegetation.

Flow within recirculation zones pulsates erratically, even when flow in the main channel is steady. Fluctuations in location of the reattachment point cause local upstream- 
Table 1. Study sites.

\begin{tabular}{|c|c|c|}
\hline Site & Mile & Bar type \\
\hline \multirow[t]{3}{*}{ Cathedral Wash } & $2.5 \mathrm{left}$ & reattachment bar \\
\hline & 31.6 right & separation bar \\
\hline & 45 left & reattachment bar \\
\hline \multirow[t]{3}{*}{ Lower Saddle Canyon } & 47.3 right & reattachment bar \\
\hline & 50.0 right & reattachment bar \\
\hline & 52 left & levee \\
\hline \multirow[t]{4}{*}{ Nankoweap } & 53 right & reattachment bar with levee \\
\hline & 54.5 right & reattachment bar \\
\hline & 55 right & reattachment bar \\
\hline & 62.6 & reattachment bar \\
\hline Carbon Creek & 64.7 right & separation bar \\
\hline Palisades & $65.6 \mathrm{left}$ & separation bar \\
\hline Tanner & 68 right & levee near separation point \\
\hline \multirow[t]{5}{*}{ Grapevine } & 81 left & reattachment bar \\
\hline & 119 right & reattachment bar \\
\hline & 119.5 right & reattachment bar \\
\hline & 122 right & reattachment bar \\
\hline & 137 left & reattachment bar \\
\hline \multirow[t]{2}{*}{ Fern Glen } & 168 right & separation bar \\
\hline & 170 left & tributary mouth \\
\hline Mohawk & 171.5 left & separation bar \\
\hline
\end{tabular}


downstream flow reversals. Ripples that are produced by this kind of reversing flow are symmetrical in profile and have crests that trend normal to the bank, whereas oscillation ripples produced by waves have crests that nearly parallel the bank. In the reversing flow at the reattachment point, rates of ripple migration are low, and rates of deposition can be rapid, causing ripples to climb at a high angle. These flow fluctuations are significant dynamically because they widen the region where the reattachment point occurs, possibly causing deposition to occur over a wider region. In addition, changes in size of a recirculation zone cause exchange of water with the mainstem flow, influencing the flux of suspended sediment. Experimental work in progress suggests that these pulsations occur even when mainstem flow is steady.

Separation bars-Three separation bars (mile 31.6 right, mile 168 right, and mile 171.5 left) have been trenched, and the structure of those bars are grossly different from the reattachment bars. As noted above, reattachment bars contain shallowing-upward depositional sequences. In contrast, the separation bars were built by a succession of deepening-upward (transgressive) cycles. The cycles are typically a few tens of centimeters thick (considerably thinner than deposits of 1983 flood deposits found in reattachment bars) and typically contain beach deposits such as swash laminae and berms.

The difference in structure between separation and reattachment bars has at least two possible interpretations: (1) deposition is initiated at different sites on the different bar types (beginning near the bank on separation bars and beginning farther offshore on reattachment bars), or (2) deposition occurs during different phases of a flood on different bar types (primarily during rising stage on separation bars but including deposition during peak or falling stage on reattachment bars). The hypothesis that reattachment-bar deposition begins offshore in relatively deep water is supported by flume experiments (Schmidt, Rubin, and Ikeda, 1993), although the second hypothesis can not be ruled out.

Levees-Levees are linear bar ridges that roughly parallel the main channel. They occur at relatively high elevation, and consist primarily of cross-strata that dip onshore. They formed at high stage, where sediment was transported out of the main channel onto floodplains or into vegetated areas. Flow in the backwaters on the landward side of the levees was commonly-but not always-directed downstream (as determined from the migration directions of ripples on the landward side of the levees); this observation indicates that deposition occurred without recirculating flow. At some sites, however, backwater flow was directed upstream. At Nankoweap, the situation is somewhat more complicated. A levee occurs within a recirculation zone. Water ponded behind that levee breached the levee and flowed in an offshore-directed jet that transported a lobe of sand into the recirculation zone. Levees are too narrow and vegetated to be used as camping beaches, but they nevertheless constitute a major kind of bar along the river.

\section{Depositional Events and Rates}

Pre-dam floods-At elevations usable for camping, the separation bar at Fern Glen contains a number of cyclic depositional sequences deposited by pre-dam floods. Each flood cycle is on the order of a few tens of centimeters thick. The thicknesses of these cycles represent the total thickness deposited by each flood.

At other locations, pre-dam deposits of climbing-ripple structures many tens of centimeters thick must also have been deposited by single floods (because individual ripples can be traced through the sequence). Total deposition for a single flood may be considerably thicker than individual sets of climbing ripples.

1983 flood-Deposits of the 1983 flood range from a few tens of centimeters at Fern Glen to a minimum of 2-3 meters on some reattachment bars (Table 2). These numbers describe the thickness of sediment deposited in 1983, not taking into account that the 1983 flood eroded pre-existing strata prior to deposition at some or all sites. De-watering structures in 
Table 2. Thickness of deposits of flow events.

\begin{tabular}{|c|c|}
\hline FLOW EVENT & \begin{tabular}{|l|} 
THICKNESS \\
\end{tabular} \\
\hline $\begin{array}{l}\text { 1983 FLOOD } \\
\text { (PEAK DISCHARGE OF } \\
\text { APPROXIMATELY 120,000 cfs; } \\
\text { TOTAL DURATION OF } \\
\text { APPROXIMATELY } 2 \text { MONTHS) }\end{array}$ & $\begin{array}{l}\text { COMMONLY TOO THICK TO TRENCH } \\
\text { THROUGH; } \\
\text { DOCUMENTED IN SOME BARS TO EXCEED } \\
\text { SEVERAL METERS }\end{array}$ \\
\hline $\begin{array}{l}\text { 1984-1986 FLOODS } \\
\text { (PEAK DISCHARGE OF } \\
\text { APPROXIMATELY 50,000 cfs; } \\
\text { TOTAL DURATION OF } \\
\text { APPROXIMATELY } 5 \text { MONTHS) }\end{array}$ & $\begin{array}{l}\text { RARELY EXCEEDS A FEW TENS OF } \\
\text { CENTIMETERS; } \\
\text { LESS WIDESPREAD THAN } 1983 \text { FLOOD } \\
\text { DEPOSITS }\end{array}$ \\
\hline $\begin{array}{l}1993 \text { FLOOD } \\
\text { (PEAK DISCHARGE OF } \\
\text { APPROXIMATELY } 30,000 \mathrm{cfs} ; \\
\text { DURATION OF } 1 \text { WEEK) }\end{array}$ & $\begin{array}{l}\text { TYPICALLY TENS OF CENTIMETERS } \\
\text { THICK; } \\
\text { MANY METERS THICK IMMEDIATELY } \\
\text { DOWNSTREAM FROM MOUTH OF LITTLE } \\
\text { COLORADO RIVER }\end{array}$ \\
\hline $\begin{array}{l}\text { DAILY POWER PLANT FLOODS } \\
\text { (PEAK DISCHARGE OF } \\
\text { APPROXIMATELY } 30,000 \mathrm{cfs} ; \\
\text { DURATION OF LESS THAN ONE } \\
\text { DAY) }\end{array}$ & $\begin{array}{l}\text { DEPOSITIONAL CYCLES RANGE IN } \\
\text { THICKNESS FROM SEVERAL } \\
\text { MILLIMETERS TO SEVERAL CENTIMETERS }\end{array}$ \\
\hline
\end{tabular}

these deposits at 119-mile bar indicate that deposition during this event was extremely rapid. The presence of these de-watering structures and massive bedding supports the idea that bar adjustment is most rapid during high-discharge events.

1984-86 floods-One of the consistent findings of this study was that the high flows of 1984-86 deposited little sediment on the bars. These deposits were restricted in area, pinching out shoreward against the topographically higher 1983 or older deposits, and commonly having been truncated on the offshore margin by subsequent power-plant flows. Where present, the 1984-86 high-flow deposits have a maximum thickness ranging from a few centimeters to approximately 1 meter. As in the case of the 1983 deposits, examining the preserved deposits can not provide information about how much sediment was eroded by 1984-86 high flows before deposition began. The onshore pinchout of these deposits is commonly situated at the base of a scarp cut into the topographically higher 1983 or predam deposits. The presence of these erosional scarps suggest that the 1984-86 floods eroded pre-existing sediment before depositing sediment.

Post-1983 fluctuating flows-Three kinds of cyclic sedimentary structures have been discovered that permit precise measurement of daily depositional rates during periods of fluctuating flow. All three structures are recognizable because of the daily changes in flow 
regime caused by the dam. Although such structures are common in tidal sand deposits, to our knowledge, such structures were unknown in rivers. The structures were formed by: (1) daily deposition of drapes on the lee side of fluvial dunes (55-mile bar; see Rubin, Schmidt, and Moore, 1990), (2) daily transgressive-regressive cycles caused by shifting beach-swash and wave-ripple facies (Lava Canyon and Stone Creek), and (3) daily bundles of climbing-ripple structures formed when ripples were created each day when the bar was inundated and planed off when flow receded (bar upstream from Fishtail Rapid, right). The sequences of cycles contain as many as several dozen uniform daily deposits. The depositional rates are quite similar for all four examples of these three structures, averaging approximately 2 to $5 \mathrm{~cm}$ per day.

Long-term rates of deposition extrapolated from these daily rates are likely to be highly inaccurate, because deposition at any one site on a bar is self-limiting. Once deposition causes the local flow conditions to change, deposition may shift to another site. In four of the five examples cited, deposition of the daily cycles occurred on inclined bar surfaces and is known to represent laterally shifting deposition. For example, although the daily cycles at 55-mile bar record local deposition of 1-2 cm/day, deposition did not persist at any one point for more than a week or two. Deposition over a wider area of the bar for a six-month time interval that spanned deposition of these daily cycles averaged approximately 0.1 $\mathrm{cm} /$ day.

\section{EVALUATION OF FLOW ALTERNATIVES}

Although stratigraphic and sedimentologic studies are important in determining how deposition creates bars, bars contain minimal stratigraphic record of erosion. For example, beds that are truncated by a discordant erosion surface indicate that erosion occurred, but volumes of eroded sediment can not be determined. Evidence for changes in bar size must come from repeated observations such as photographs or topographic mapping. In this discussion, we rely on previous work (Beus, Carothers, and Avery, 1985; Schmidt and Graf, 1990; Clark, Kyle, and Schmidt, 1991) to document that bar erosion has been occurring, and we use what we have learned of depositional processes to evaluate the proposed flow alternatives.

Flow regime affects bars in three ways: (1) frequency and duration of bar submergence, (2) bar dynamics, and (3) net sediment budget in the canyon. These three processes operate on different time scales. On the shortest time scale, bars are instantaneously lost as campsites when they become submerged, regardless of any erosion or deposition. Deposition and erosion also operate on an intermediate time scale and can destroy bars by transferring sand from high-elevation (emergent) locations to the submerged channel. On a longer time scale (decades), flow regime influences the rate at which sediment is transported down the main channel, thereby determining the net sediment budget through the canyon. Bars can thus become unusable for camping because they are submerged, because they are eroded (sand transferred to the main channel), or because the entire canyon becomes depleted of sand. Those processes that operate over longer periods of time are more difficult to reverse.

These three processes are largely independent. For example, a single flow alternative may build bars for a short time (by flushing sand from pools to bars) but simultaneously contribute to the long-term depletion of sand in the canyon (by flushing sand out of the canyon). Thus, a single flow alternative may erode the same bars initially built. Although the short- and intermediate-term effects (inundation and aggradation or degradation) are easier to monitor than long-term effects (sediment depletion throughout the canyon), the long-term effects are potentially a more serious threat to the future of the canyon environment. If the canyon becomes depleted of sand, decades may be required to restore the sand. During restoration, options for building bars would be severely restricted; without sand in storage, flows that might otherwise build bars would fail. Any plan for 
dam operation must take into account the effects of all three effects: submergence, dynamic adjustments, and sand budget.

Two measures were used to evaluate the extent to which the alternative flows submerge bars. The first uses cumulative frequency curves for the seven flow alternatives to determine the percentage of days during a minimum-release year ( 8.2 million acre-ft) that discharge does not exceed 15,000 cfs (Figs. 4-10). These percentages, which are summarized in Table 3, range from a maximum of 100 percent emergence (for year-round steady flow) to a minimum of $30-35$ percent emergence (for flows with large daily fluctuations). For a given daily release, fluctuating flows inundate higher elevations each day than do steady flows.

It is also instructive to evaluate the extent to which the flow of each alternative inundates the deposits produced by that alternative. The 90 th percentile of high flows was used to approximate beach-building discharge for each flow alternative (because of the exponential increase in sediment transport rate with increasing discharge, and because the terraced depositional structure of the bars indicates that deposition commonly proceeds to an elevation that approaches the water surface during high flows, as illustrated in Figure 3). Deposits were defined to be usable for camping on days during which river stage stayed at least $10,000 \mathrm{cfs}$ below the 90 th percentile beach-building discharge (Figs. 4-10). Using this measure, bar accessibility was determined to be 50 percent of days during the year for seasonally adjusted steady flow, and 0-10 percent (for all other flows). For comparison, the accessibility of deposits of the 90th percentile beach-building flows of a pre-dam flow year (1957) is 85 percent (Fig. 11). Although the 90th percentile and 10,000 cfs specifications are somewhat arbitrary, the relative ranking of the seven flow alternatives and pre-dam conditions is rather insensitive to the particular values selected.

To build bars that can be used for camping requires the transfer of sand from elevations that are normally submerged to elevations that are subaerially exposed for time intervals longer than 24 hours. Because this can only be done by flows that vary on a time scale that is much longer than one day, it may be necessary or desirable to produce experimental barbuilding flows. Without bar-building flows, seasonally adjusted steady flow offers the greatest possibility of transferring sand to elevations that are emergent for most of the year. Experimental bar-building flows combined with either year-round steady flow or existing monthly volume steady flow might result in a flow regime that crudely resembles the seasonally adjusted steady flow alternative. However, experimental flows offer greater flexibility in maximizing bar-building and minimizing sand transport out of the canyon.

We emphasize that it is essential to consider all kinds of effects of flow regime on bars (submergence/emergence of bars, deposition/erosion of bars, and sediment budget in the canyon). Without such consideration, a flow alternative that was selected because of shortterm bar-building effects may contribute to the long-term depletion of sand in the canyon or may result in fewer available campsites merely because of daily submergence.

Other elements of the flow alternatives include such possibilities as sand augmentation and beach-building flows. Sand augmentation would have a positive effect on the sand budget and would allow greater flexibility in what kinds of bar building flows could be adopted. Even without sand augmentation, it may be possible to design bar-building flows that can transfer sand from the subaqueous channel to parts of the bars that are subaerially exposed during the remainder of the year. 


\section{YEAR-ROUND STEADY FLOW}

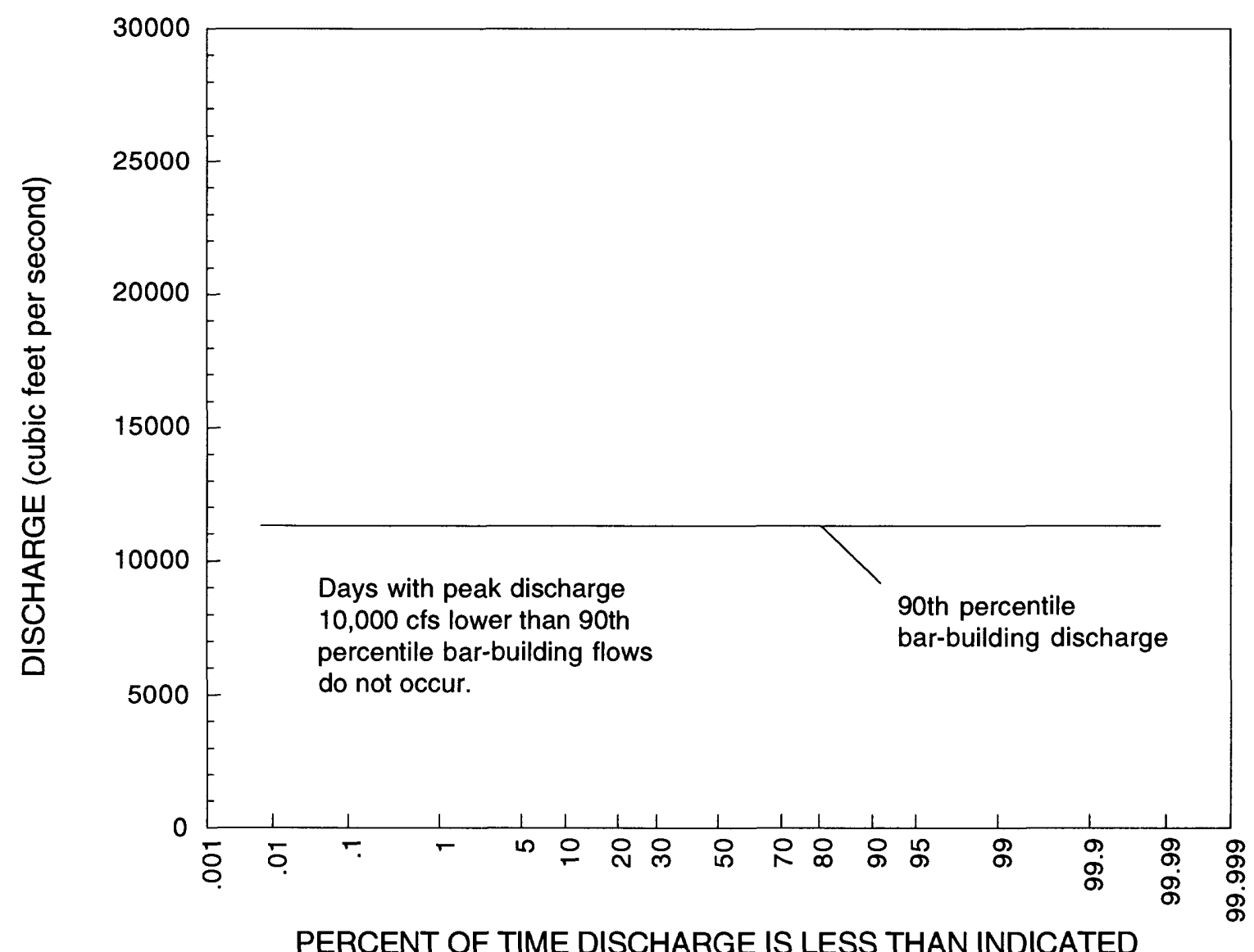

Figure 4. Cumulative frequency plot for the year-round steady flow alternative. Annual release is 8.2 million acre feet. This alternative maximizes the subaerial exposure of preexisting deposits, because discharge is low throughout the year, but any deposits that might be produced by this flow are inaccessible for camping (submerged) throughout the year. 


\section{SEASONALLY ADJUSTED STEADY FLOW}

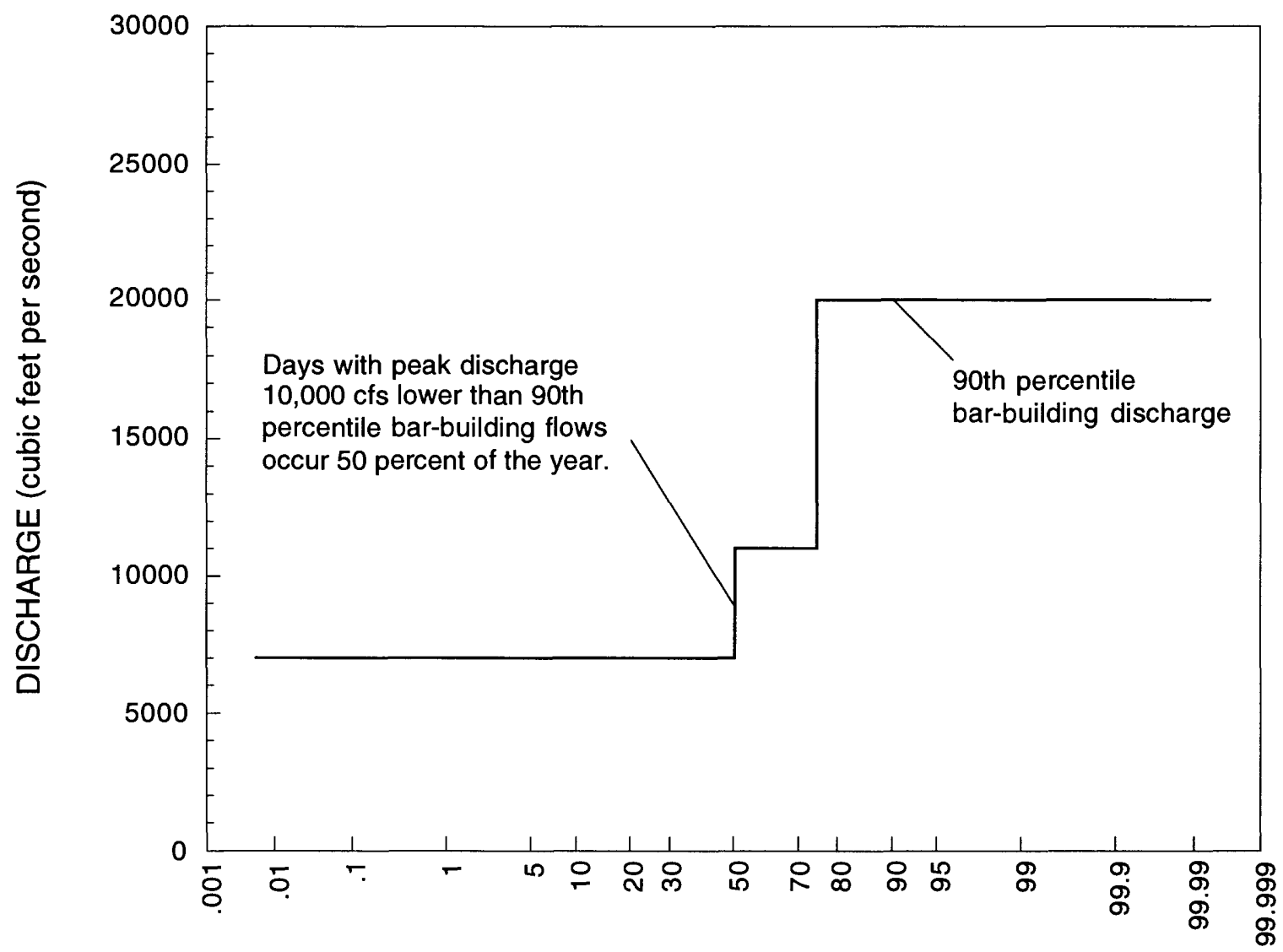

PERCENT OF TIME DISCHARGE IS LESS THAN INDICATED

Figure 5. Cumulative frequency plot for the seasonally adjusted steady flow alternative. Annual release is 8.2 million acre feet; monthly releases were determined using the example provided by T.J. Randle (U.S. Bureau of Reclamation, written communication, 1991). The 90th percentile bar-building flow is $20,000 \mathrm{cfs}$; deposits emergent at $10,000 \mathrm{cfs}$ are available for camping for 50 percent of the days of the year. Without the addition of specific bar-building flows, this alternative has the best combination of brief high discharge (to deposit sediment at high elevations) and longer low discharge (to allow access to the deposited sediment). Bar availability is somewhat more limited than implied, because the highest discharges occur during some of the months of high demand for campsites. 


\section{EXISTING MONTHLY VOLUME STEADY FLOW}

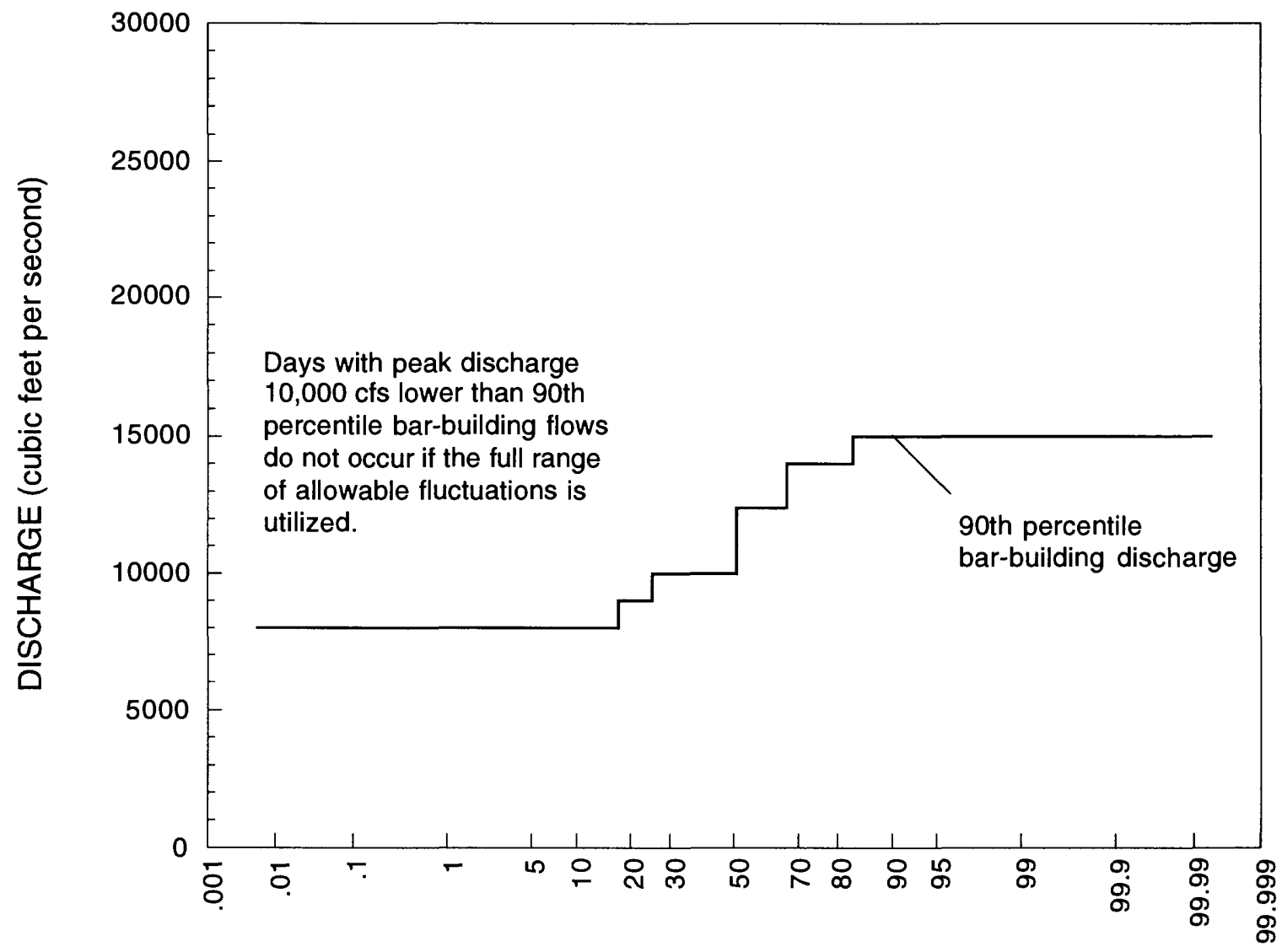

PERCENT OF TIME DISCHARGE IS LESS THAN INDICATED

Figure 6. Cumulative frequency plot for the existing monthly volume steady flow alternative. Annual release is 8.2 million acre feet; monthly releases were determined using the example provided by T.J. Randle (U.S. Bureau of Reclamation, written communication, 1991). Because of the limited annual range in flow, any sediment deposited during highwater months can only be a small height above water even during low-water months. 


\section{LOW DAILY FLUCTUATIONS}

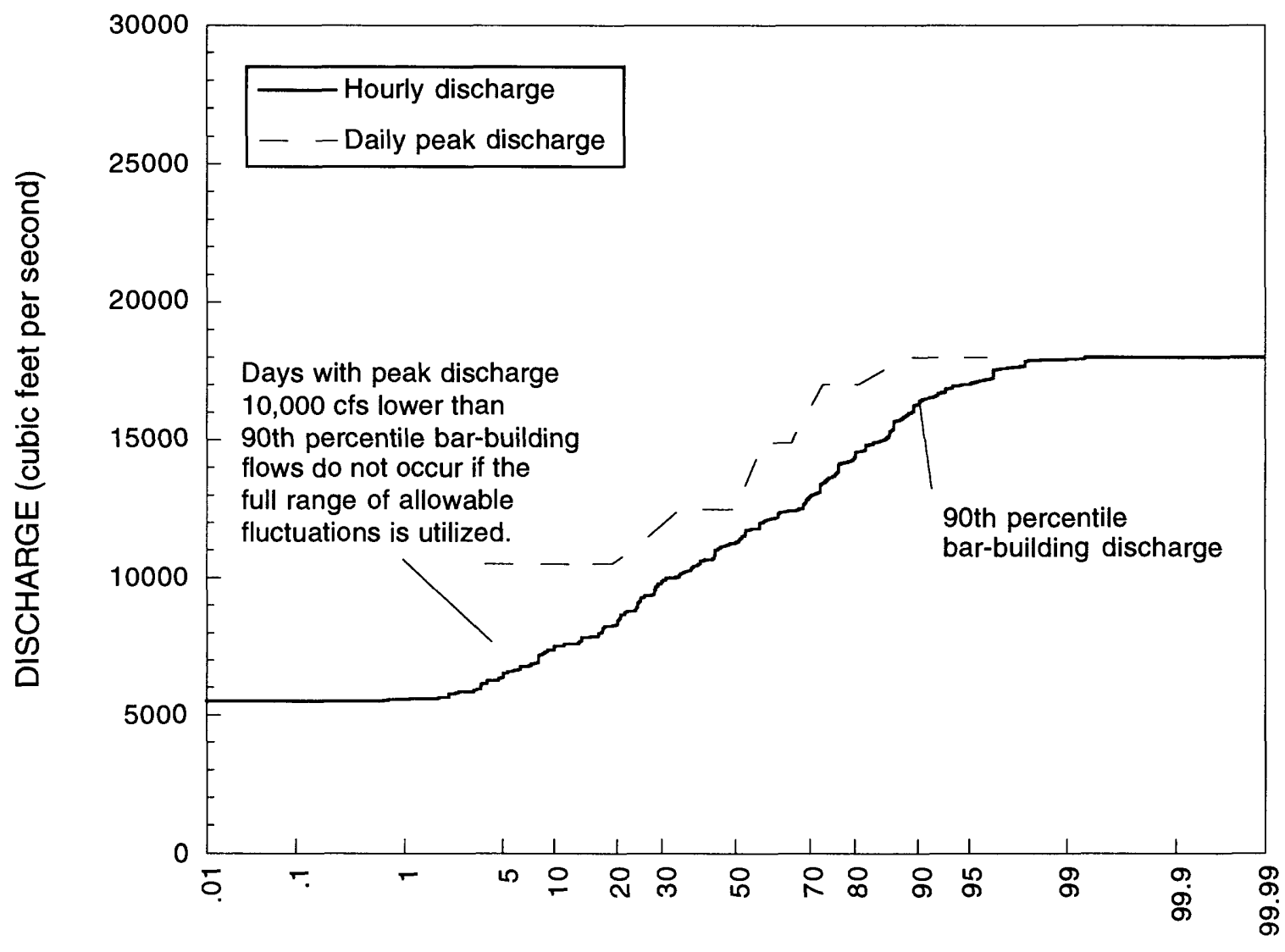

PERCEN OF TIME DISCHARGE IS LESS THAN INDICATED

Figure 7. Cumulative frequency plot for the low fluctuating flow alternative. Annual release is 8.2 million acre feet. An annual hypothetical discharge curve was synthesized using a computer program J.P. Bennett, U.S. Geological Survey, written communication, 1991) that imposes the specified daily fluctuations and minimum discharge on a specified monthly release. Sediment deposited during times of 90 th percentile high water is seldom available for camping because of the limited annual range in discharge. 


\section{MODERATE DAILY FLUCTUATIONS}

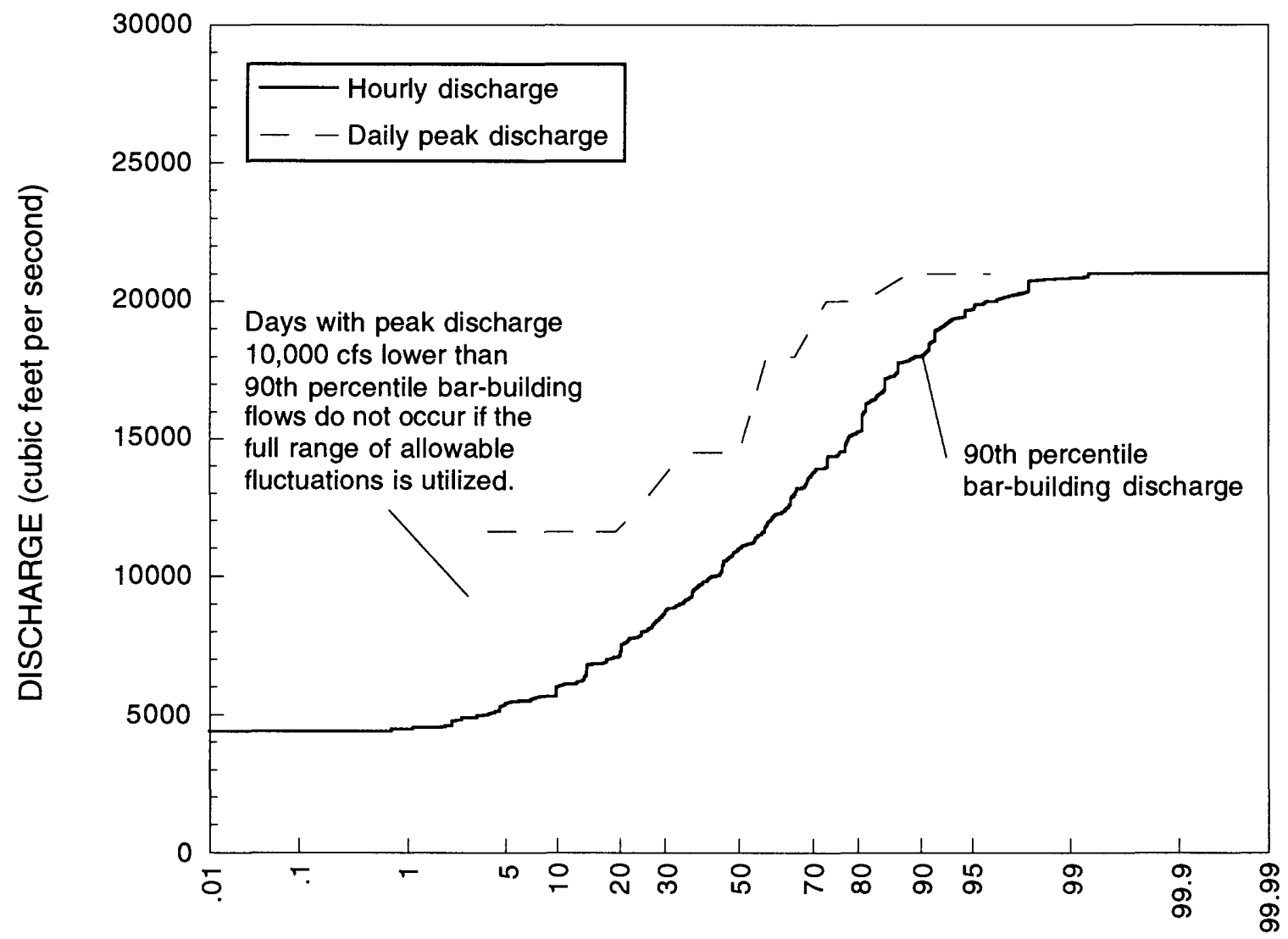

PERCENT OF TIME DISCHARGE IS LESS THAN INDICATED

Figure 8. Cumulative frequency plot for the moderate fluctuating flow alternative. Monthly releases are the same as in Figure 6, but daily fluctuations are larger. This flow has higher maximum flows than the low fluctuating flows, providing the potential for depositing sediment at higher elevations. This benefit, however, is offset by the correspondingly greater daily fluctuations, which inundate higher elevations. 


\section{HIGH FLUCTUATIONS}

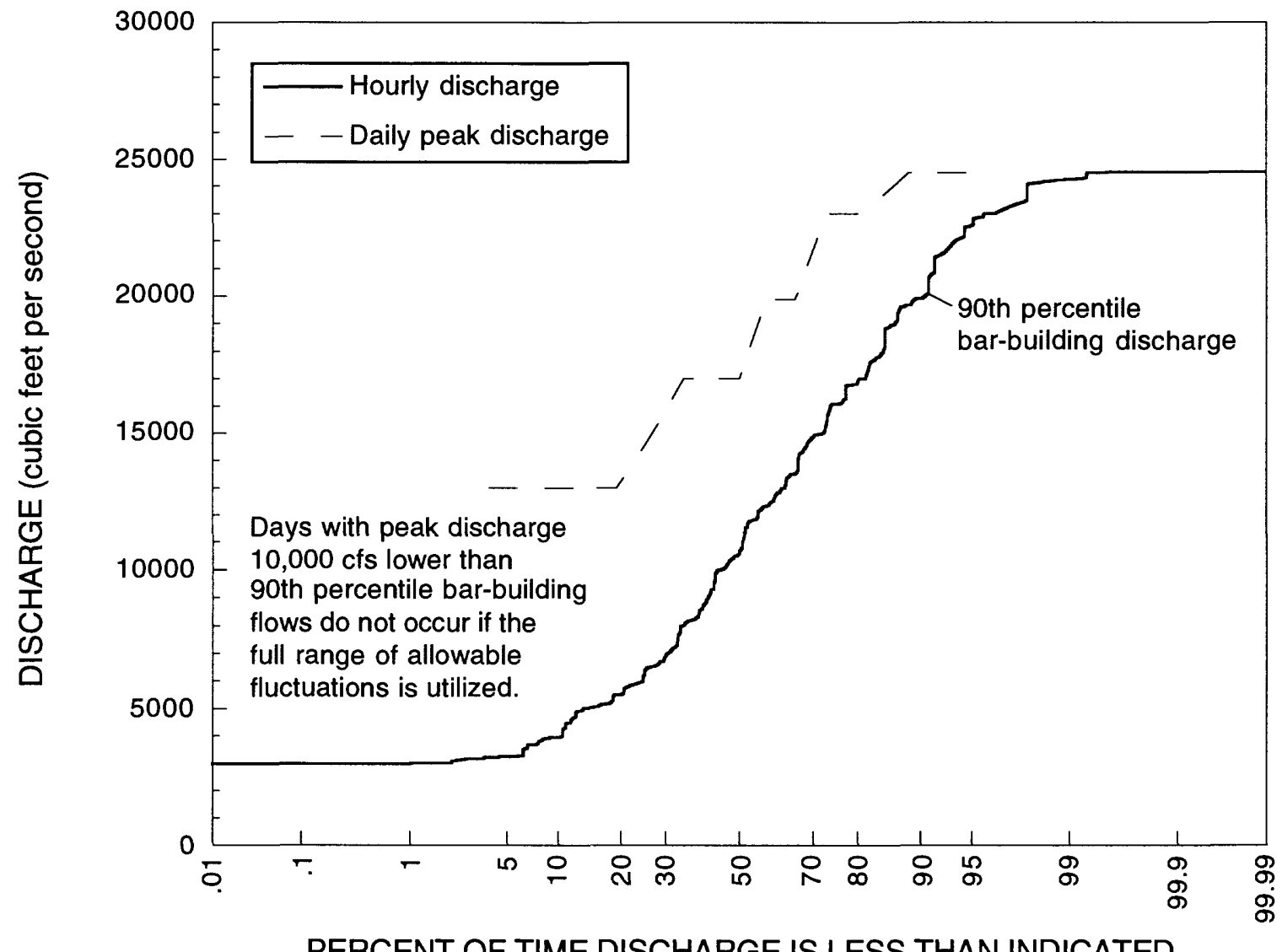

PERCENT OF TIME DISCHARGE IS LESS THAN INDICATED

Figure 9. Cumulative frequency plot for the high fluctuating flow alternative. Monthly releases are the same as in Figures 6 and 7, but daily fluctuations are larger. 
NO ACTION (1989 FLOW)

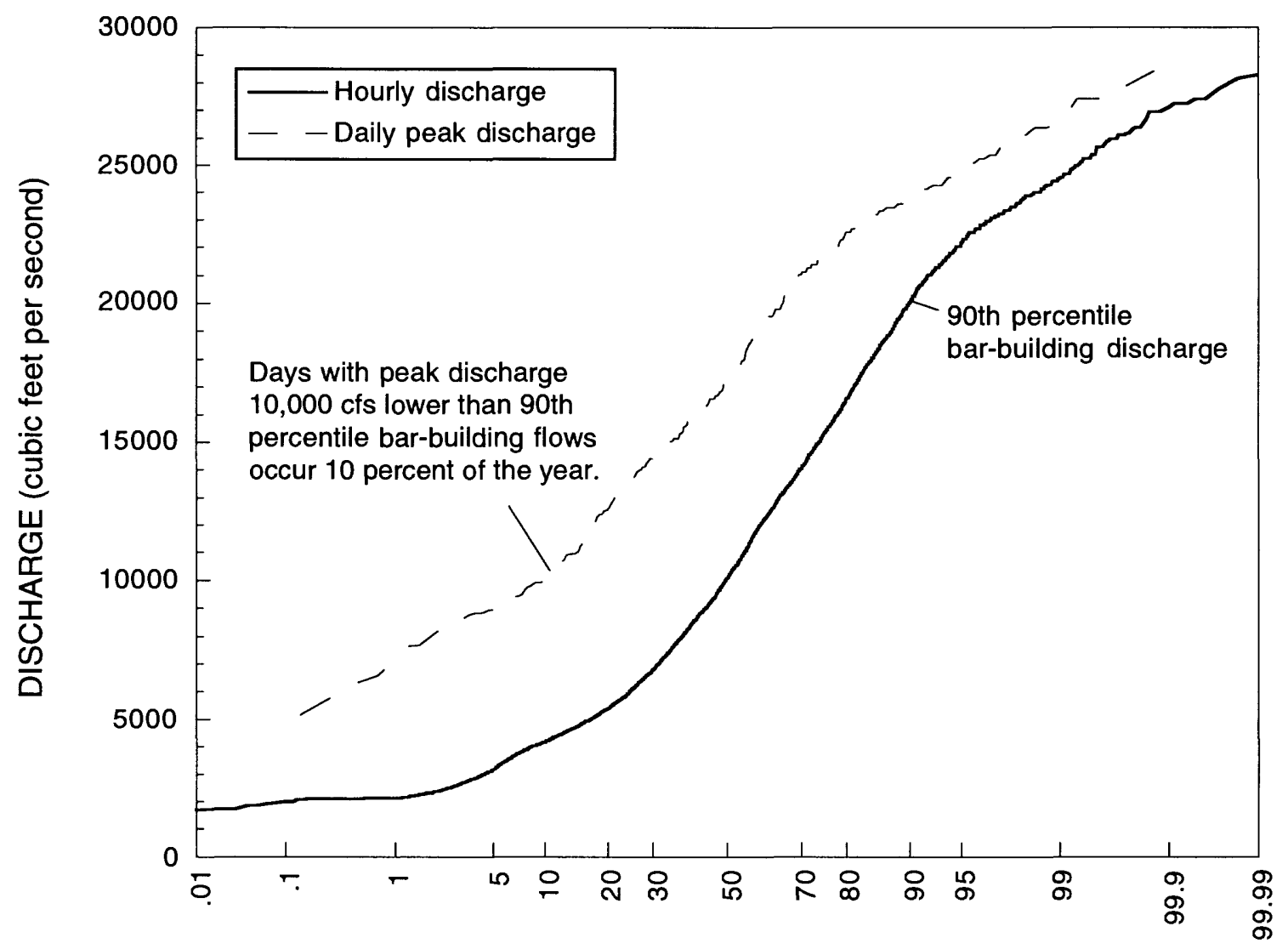

PERCENT OF TIME DISCHARGE IS LESS THAN INDICATED

Figure 10. Cumulative frequency plot for the no-action flow alternative. Deposits of high flows (20,000 cfs and above) are accessible for camping approximately 10 percent of the days of the year when daily peak discharge does not exceed 10,000 cfs. 


\section{PRE-DAM (1957 FLOW)}

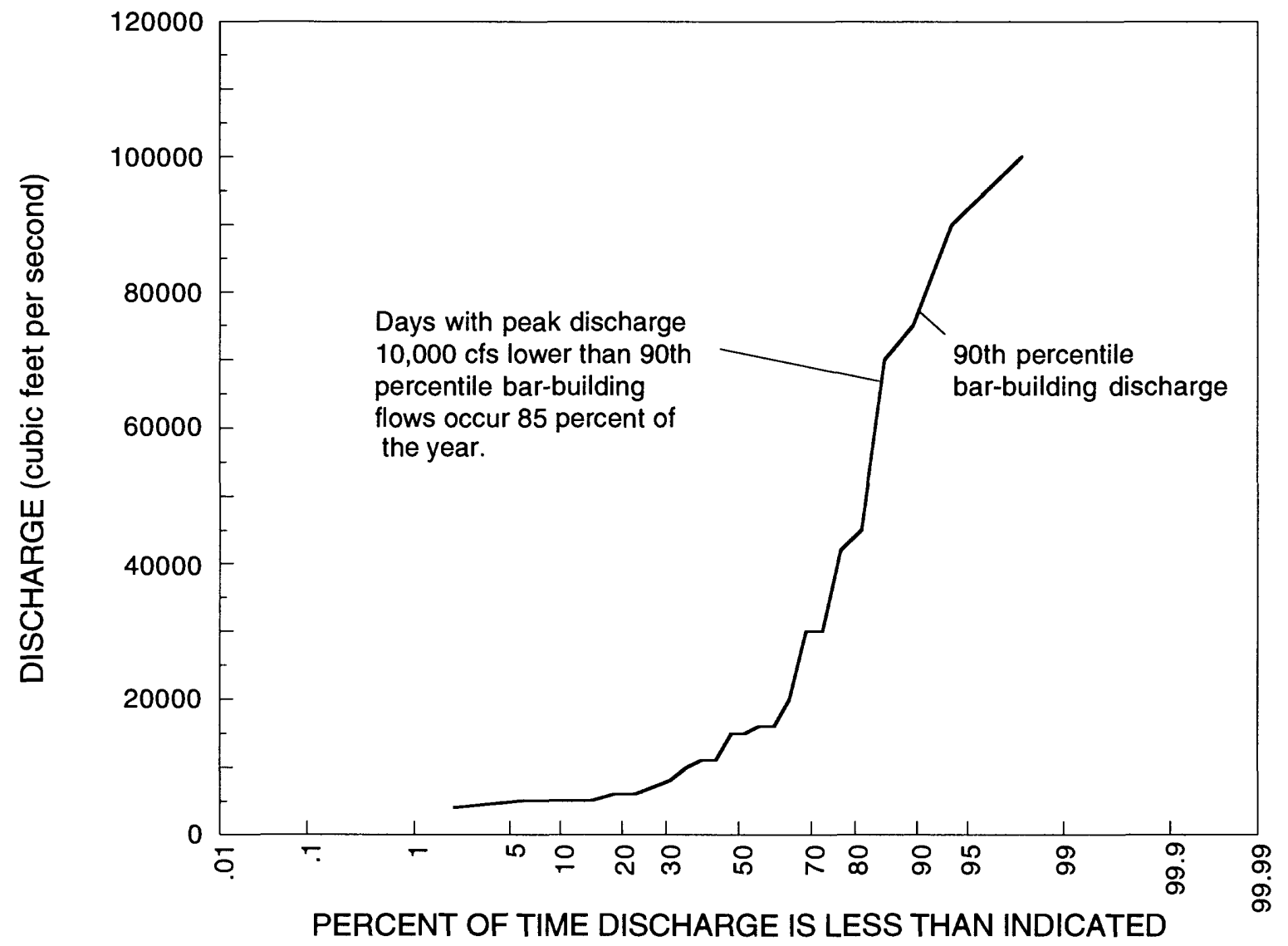

Figure 11. Cumulative frequency plot for a pre-dam year (1957). Deposits of 90th percentile high flows (approximately $80,000 \mathrm{cfs}$ and above) are accessible for camping 85 percent of the days of the year when daily peak discharge does not exceed 70,000 cfs. Scale differs from Figures 4-10. 
Table 3. Effects of proposed alternative flows on bar accessibility (emergence).

\begin{tabular}{|c|c|c|c|c|c|c|c|}
\cline { 2 - 7 } \multicolumn{1}{c|}{} & \multicolumn{3}{c|}{ Steady flows } & \multicolumn{3}{c|}{ Fluctuating flows } \\
\cline { 2 - 8 } Effect & 1 Year-round & $\begin{array}{c}{ }^{1} \text { Seasonally } \\
\text { adjusted }\end{array}$ & $\begin{array}{c}{ }^{1} \text { Existing } \\
\text { monthly } \\
\text { volume }\end{array}$ & ${ }^{2}$ Low & 2 Moderate & 2 High & $\begin{array}{c}{ }^{3} \text { No action } \\
\text { (same } \\
\text { limits as } \\
\text { before } \\
\text { interim } \\
\text { flows) }\end{array}$ \\
\hline $\begin{array}{c}\text { Accessibility of all } \\
\text { bars, regardless of } \\
\text { discharge that created } \\
\text { the bars (\% of days } \\
\text { that discharge does not } \\
\text { exceed 15,000 cfs) }\end{array}$ & 100 & 75 & 100 & 70 & 650 & 630 & 635 \\
\hline $\begin{array}{c}\text { Percentage of days in } \\
\text { which high-flow } \\
\text { deposits of each flow } \\
\text { alternative are } \\
\text { accessible for camping } \\
\text { throughout the year }\end{array}$ & 0 & 550 & 0 & 60 & 60 & 60 & 610 \\
\hline
\end{tabular}

${ }^{1}$ Steady flows that were evaluated were those provided by T.J. Randle (U.S. Bureau of Reclamation, written communication, 1991); annual release is 8.2 million acre feet.

2 The low, moderate, and high fluctuating flows that were evaluated were hypothetical discharge curves synthesized using a computer program (J.P. Bennett, U.S. Geological Survey, 1991, written communication) that imposes the specified daily fluctuations and minimum discharge on a specified monthly release; annual release is 8.2 million acre feet. Differences between the three synthetic fluctuating flows and the observed no-action fluctuating flow may be due in part to the scheme used to synthesize the predicted discharges.

${ }^{3}$ These flows were evaluated using discharges measured hourly at Lees Ferry in 1989; annual release was 8.2 million acre feet.

${ }^{4}$ Bar-building flows (see text) could increase this rating for all flow alternatives.

$5^{5}$ The months of submergence occur during some of the months of greatest recreational use.

${ }^{6}$ Accessibility is limited to those days on which discharge is low and fluctuations are less than the maximum allowable. Such flows occur on weekends and apparently contribute to the 10 percent rating of the "no action" alternative. Low weekend flows are not built in to the computer model used to synthesize hypothetical discharge curves; campers can not predict which days the discharge will remain low.

${ }^{7}$ See text for quantitative determination of this effect.

\section{CONCLUSIONS}

Three kinds of effects must be considered when evaluating the effect of flow alternatives on camping beaches (submergence/emergence of bars, erosion/deposition of bars, and net sediment budget in the canyon). A relatively large annual fluctuation and small daily fluctuation allows deposition at high elevations for a short time and allows emergence through most of the year. Low daily fluctuations allow camping on bars that otherwise would be inundated daily. 


\section{REFERENCES}

Baker, V.R., 1984, Flood sedimentation in bedrock fluvial systems: in: Koster, E.H. and Steel, R.J., eds., Sedimentology of Gravels and Conglomerates: Canadian Society of Petroleum Geologists, Memoir 10, p. 87-98.

Baker, V.R., Kochel, R.C., Patton, P.C., and Pickup, G., 1983, Paleohydrologic analysis of Holocene flood slack-water sediments, in: Collinson, J.D., ed., Modern and Ancient Fluvial Sediments: International Association of Sedimentologists Spec. Publ. 6, p. 229-239.

Beus, S.S., Carothers, S.W., and Avery, C.C., 1985, Topographic changes in fluvial terrace deposits used as campsite beaches along the Colorado River in Grand Canyon: Jour. Arizona-Nevada Acad. Science, v. 20, p. 111-120.

Clark, J.J., Kyle, E.L., and Schmidt, J.C., 1991, Mapping sediment-storage changes along the Colorado River in Grand Canyon, Arizona [abs.]: EOS, Trans. Am. Geophysical Union, v. 72, p. 223.

Howard, A.D., and Dolan, R., 1981, Geomorphology of the Colorado River: Journal of Geology, v. 89, p. 269-298.

Leeder, M.R., and Bridges, P.H., 1975, Flow separation in meander bends: Nature, v. 253, p. 338-339.

McKee, E.D., 1938, Original structures in Colorado River flood deposits of Grand Canyon: Jour. Sed. Petrology, 8, 77-83.

Nanson, G.C., and Page, K., 1983, Lateral accretion of fine-grained concave benches on meandering rivers, in: Collinson, J.D., ed., Modern and Ancient Fluvial Systems: International Association of Sedimentologists Spec. Publ. 6, p. 133-143.

Page, K., and Nanson, G.C., 1982, Concave-bank benches and associated floodplain formation: Earth Surface Processes and Landforms, v. 7, p. 529-543.

Rouse, H., Bhoota, B.V., and Hsu, En-Yun, 1951, Design of channel expansions: Transactions of the American Society of Civil Engineers, v. 116, p. 347-363.

Rubin, D.M., Schmidt, J.C., and Moore, J.N., 1990, Origin, structure, and evolution of a reattachment bar, Colorado River, Grand Canyon, Arizona: Journal of Sedimentary Petrology, v. 60, p. 982-991.

Schmidt, J.C., 1990, Recirculating flow and sedimentation in the Colorado River, Grand Canyon, Arizona: Jour. Geology, v. 98, p. 709-724.

Schmidt, J.C., and Graf, J.B., 1990, Aggradation and degradation of alluvial sand deposits, 1965 to 1986, Colorado River, Grand Canyon National Park, Arizona. U.S. Geological Survey Professional Paper 1493, 74 pp.

Schmidt, J.C., Rubin, D.M., and Ikeda, H., 1993, Flume simulation of recirculating flow and sedimentation: Water Resources Research, v. 29, p. 2925-2939.

Taylor, G., Crook, K.A.W., and Woodyer, K.D., 1971, Upstream-dipping foreset crossstratification: origin and implications for paleoslope analyses: Jour. Sed. Petrology, v. 41, p. $578-581$. 


\section{APPENDIX (OBSERVATIONS OF INTERNAL STRUCTURE)}

This APPENDIX consists of figures showing stratigraphic sequences in the larger trenches and pits that have been excavated. These figures are included to document the structures observed and to illustrate the extent of observations used to develop an understanding of depositional processes. The figures are arranged by distance downstream. 


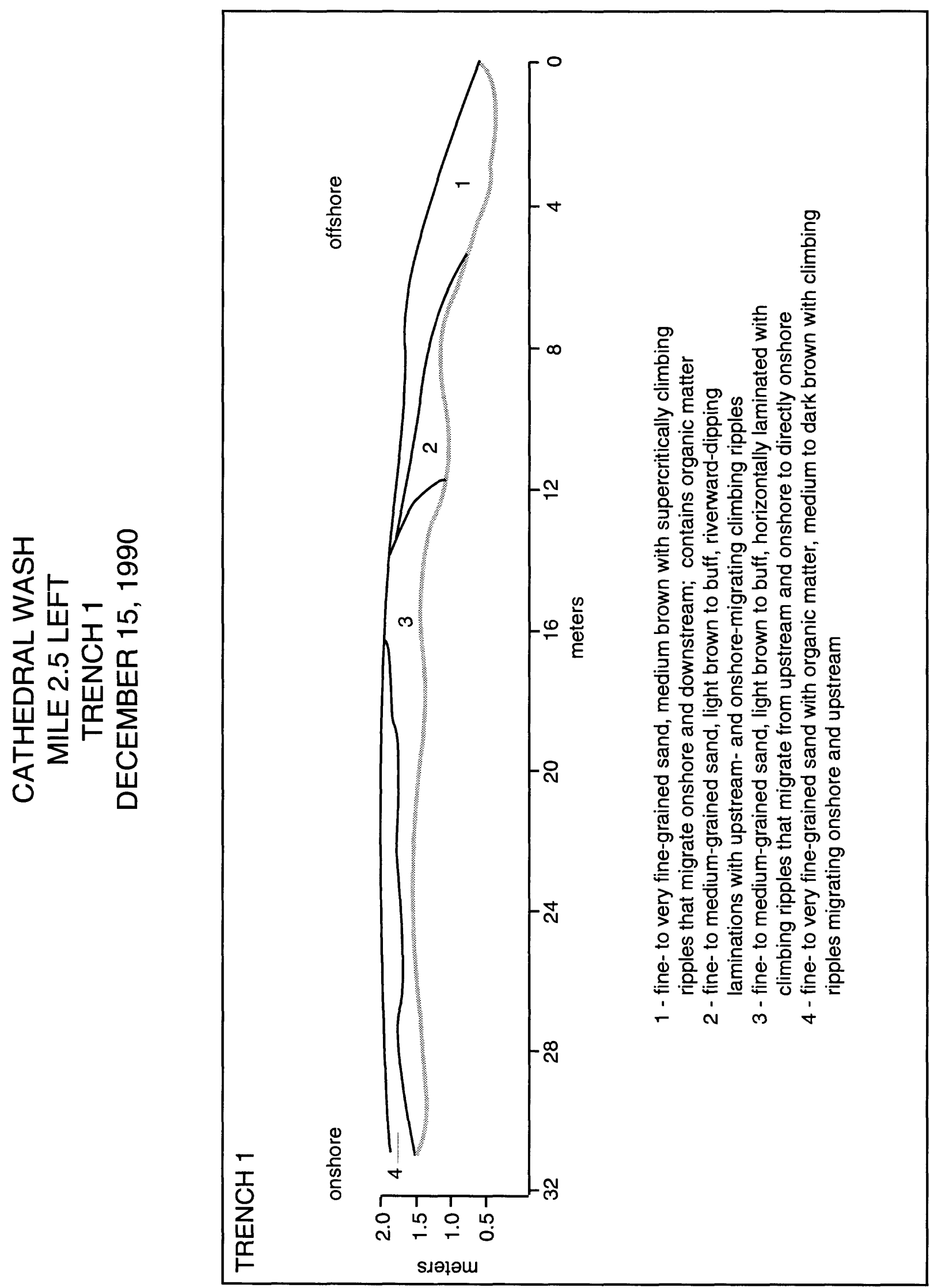




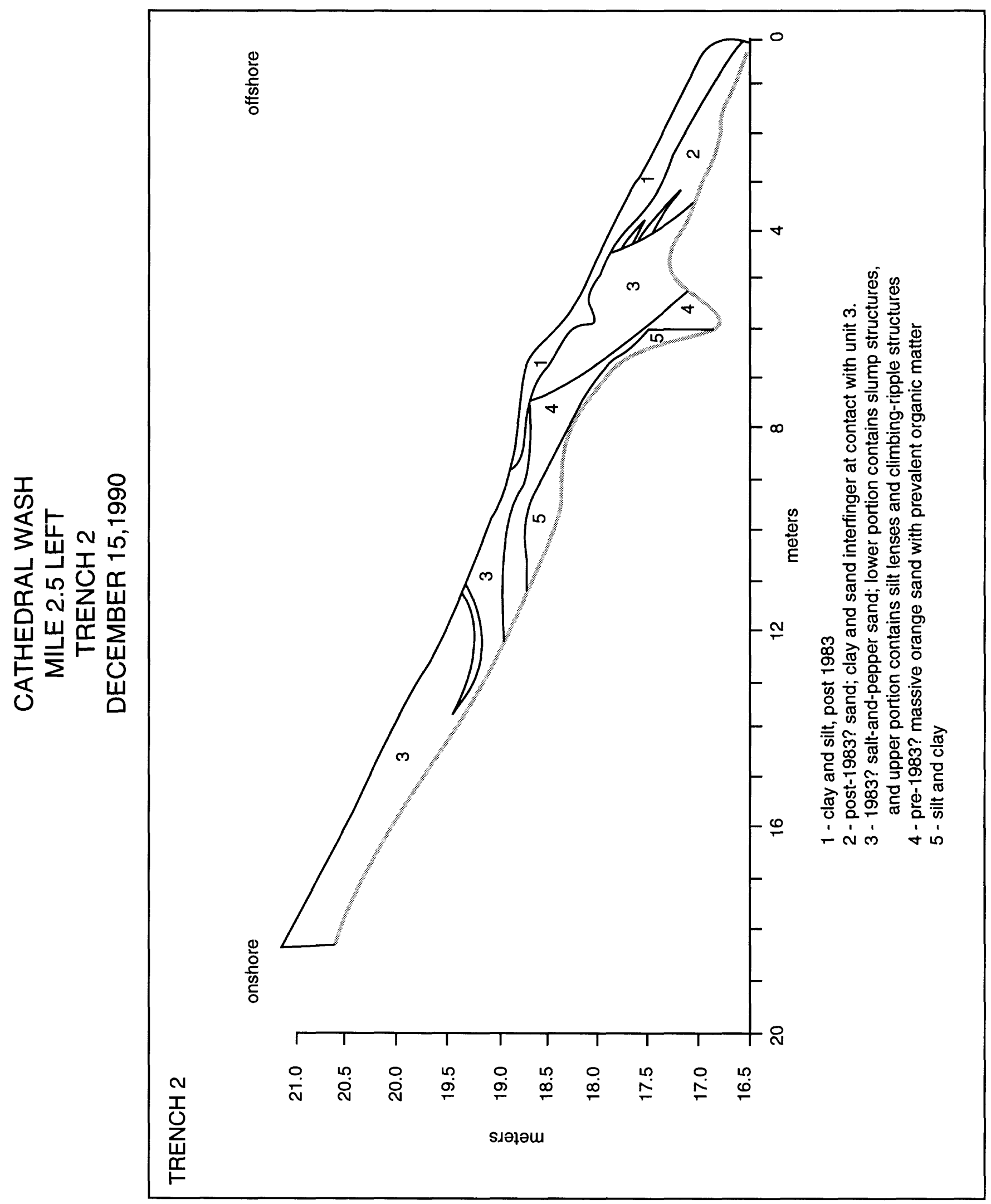




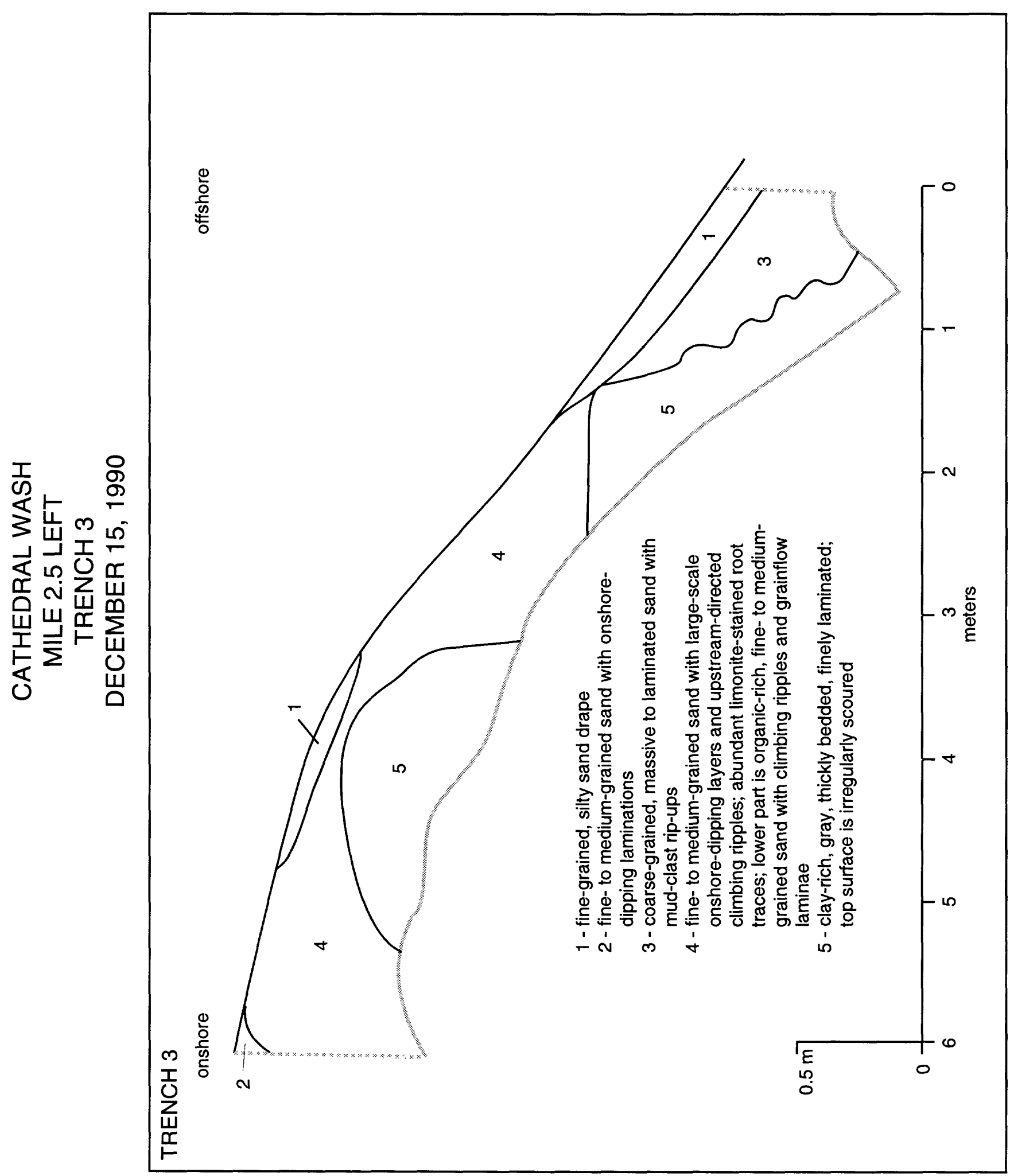




\section{CATHEDRAL WASH \\ MILE 2.5 LEFT \\ TRENCH 4 \\ DECEMBER 15, 1990}

\section{TRENCH 4}

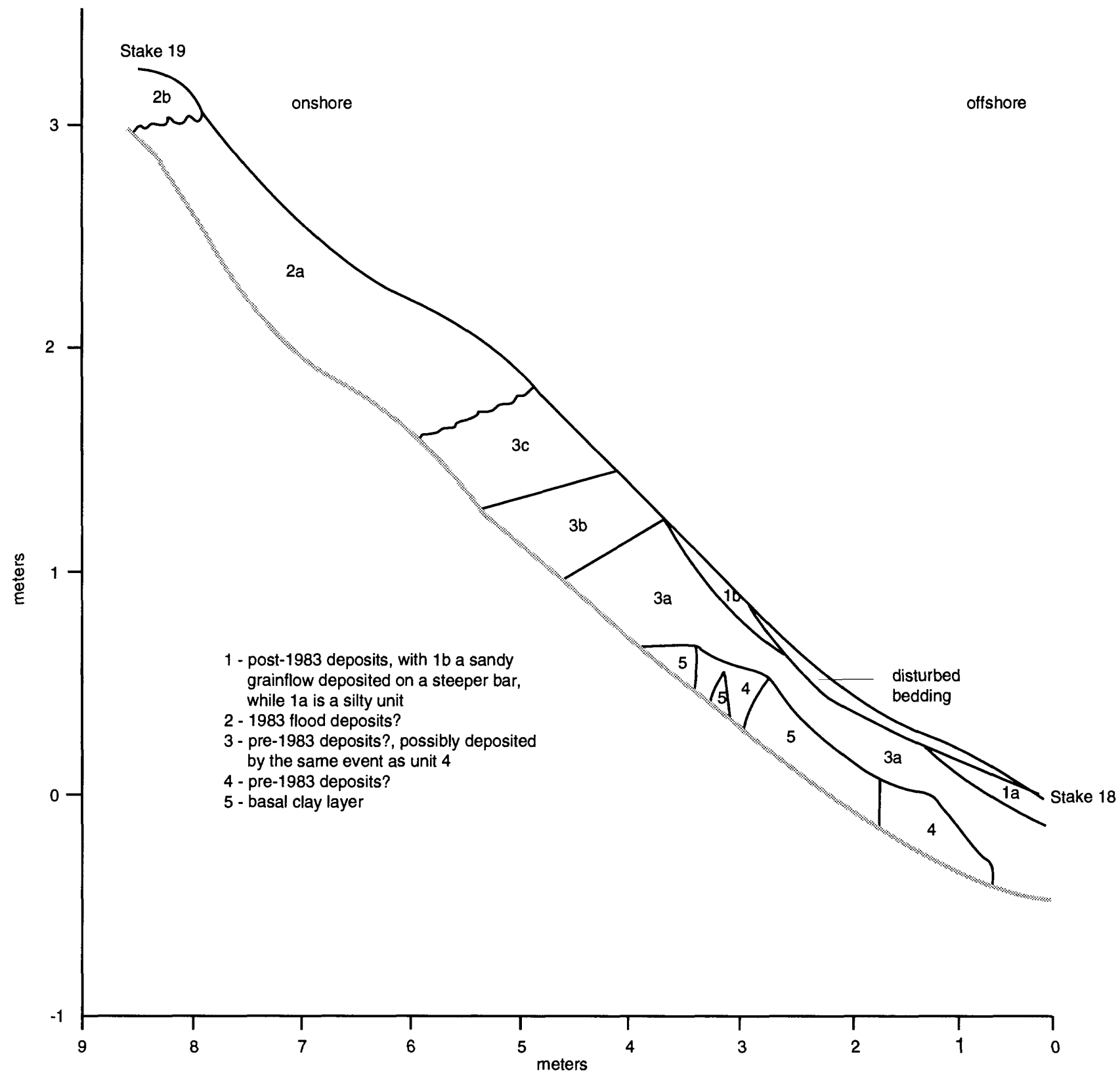




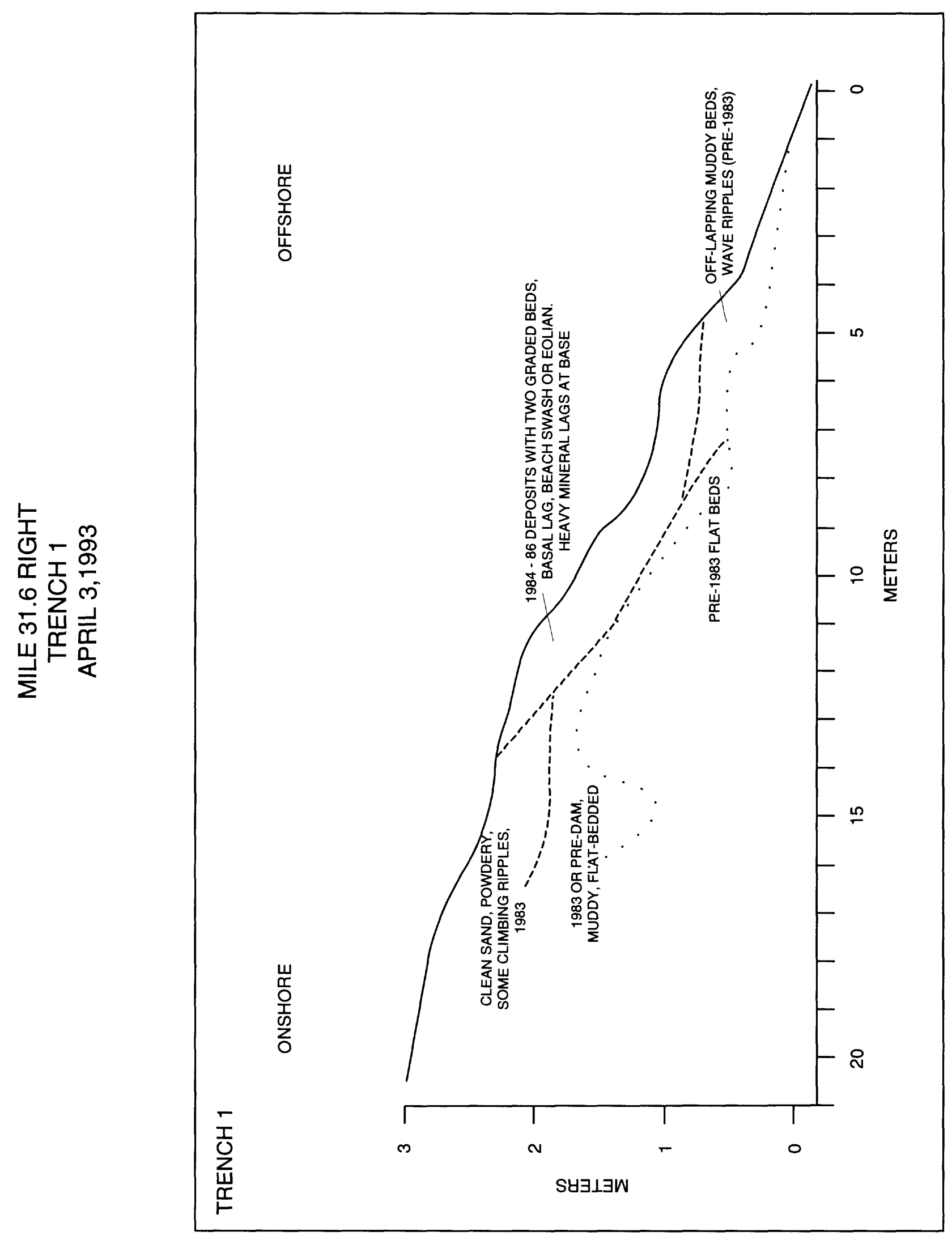




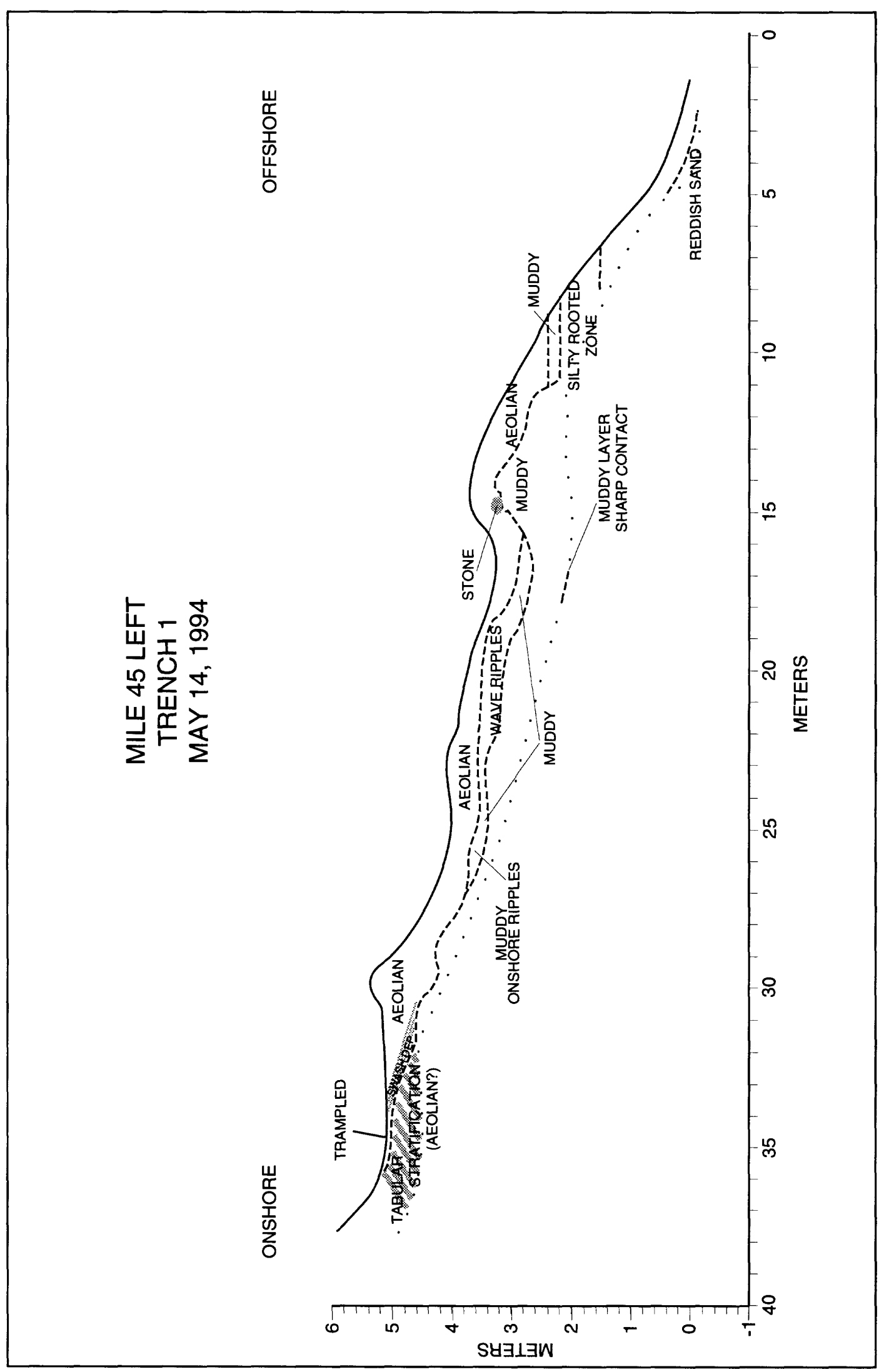




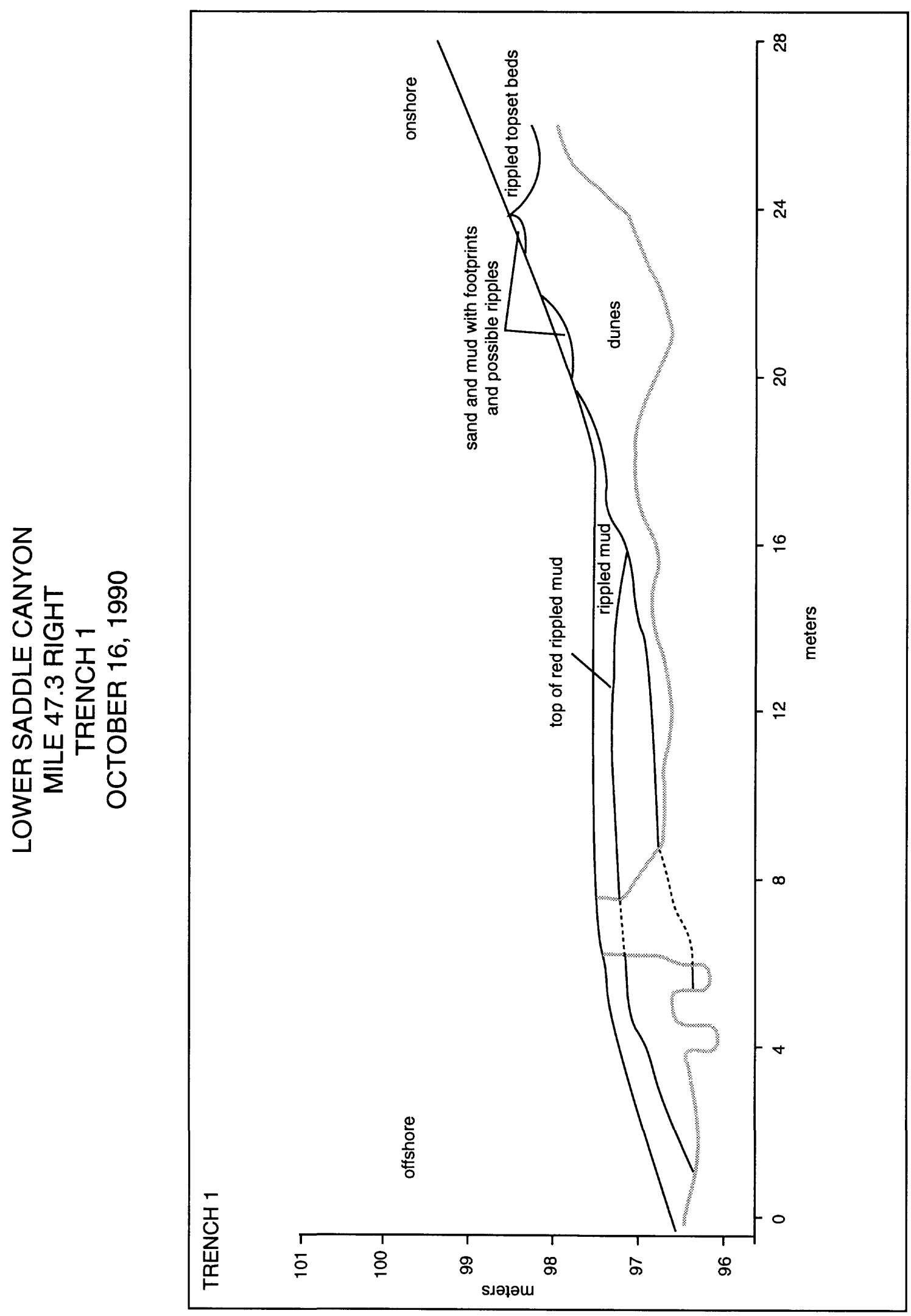




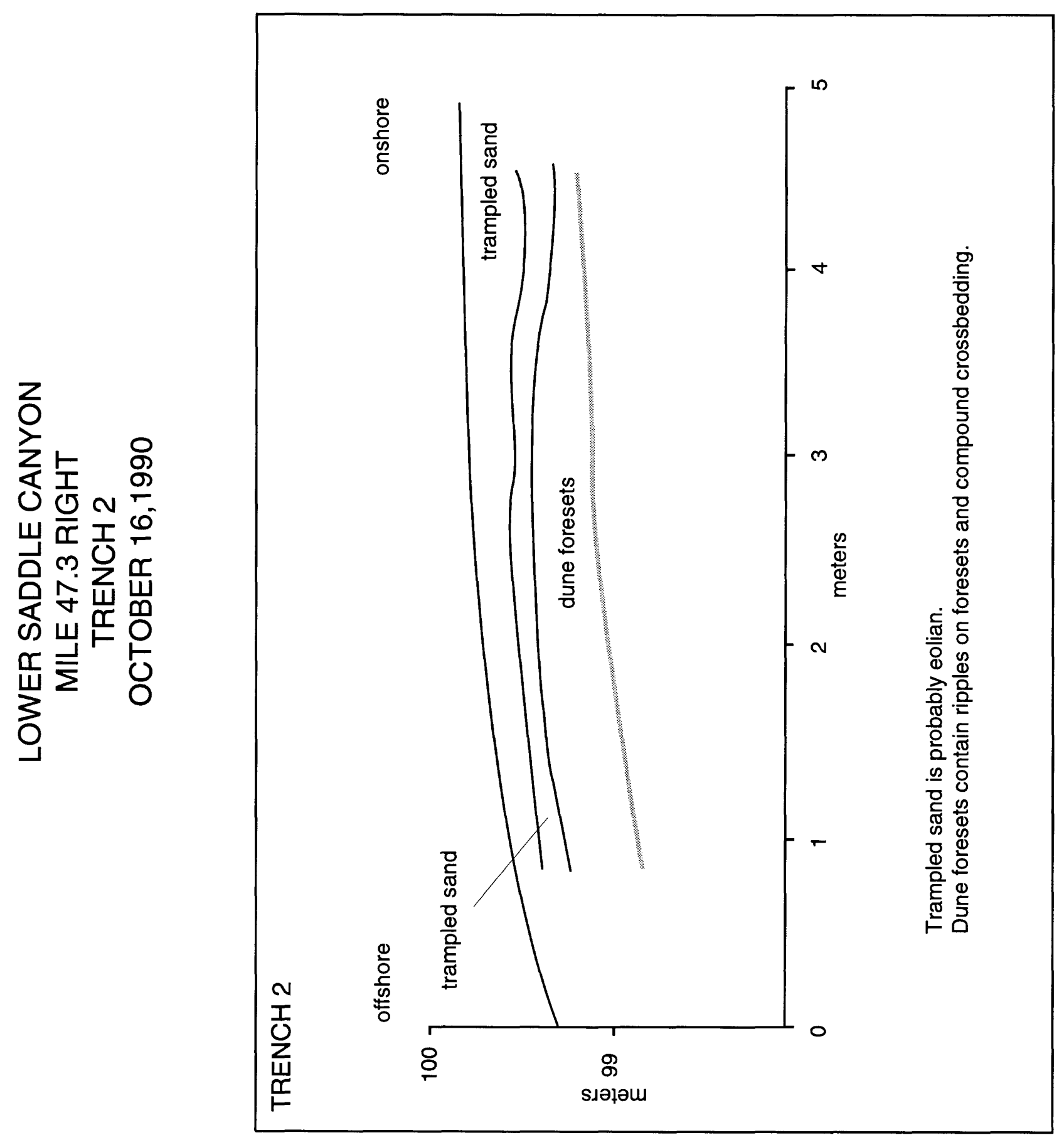




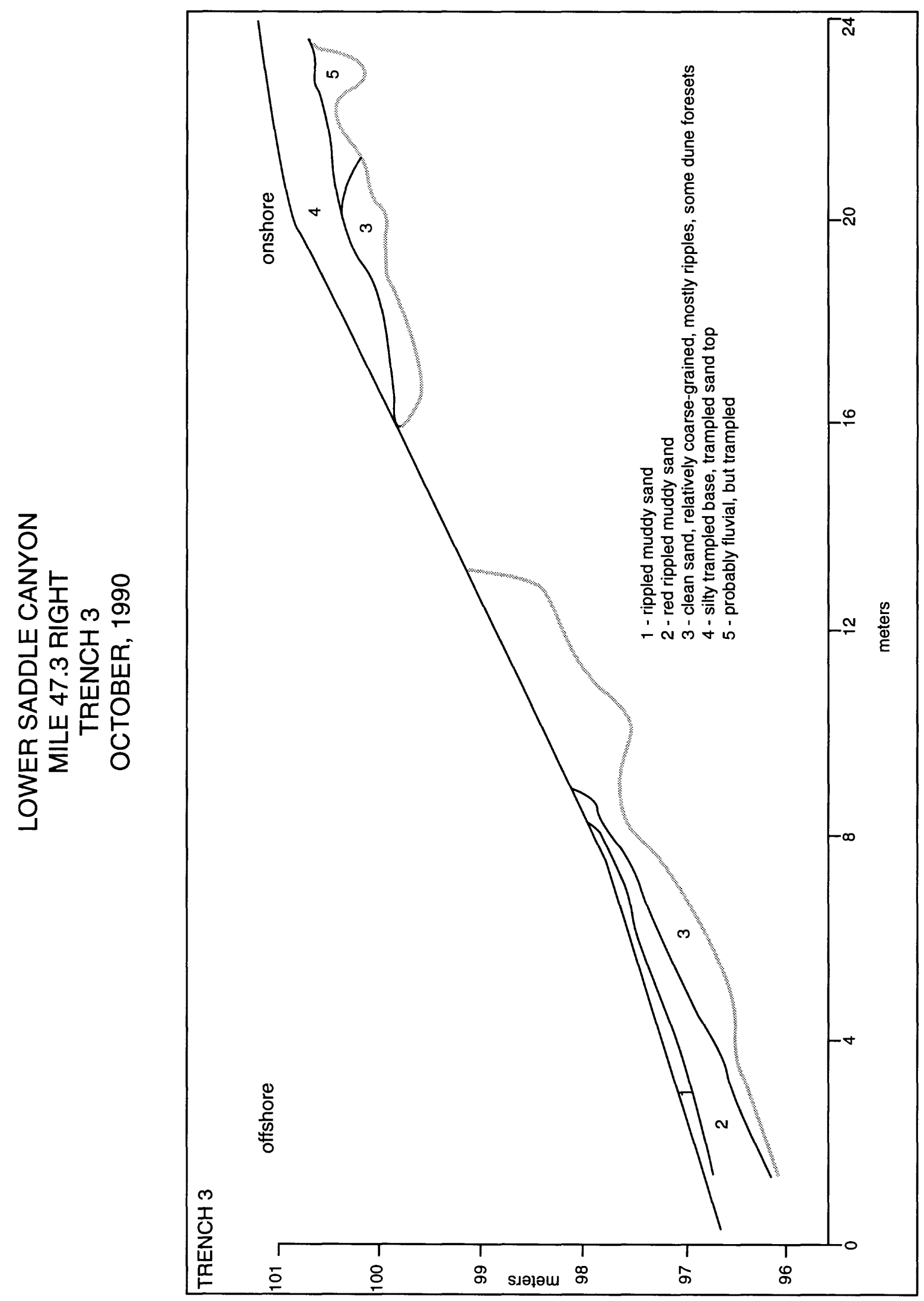




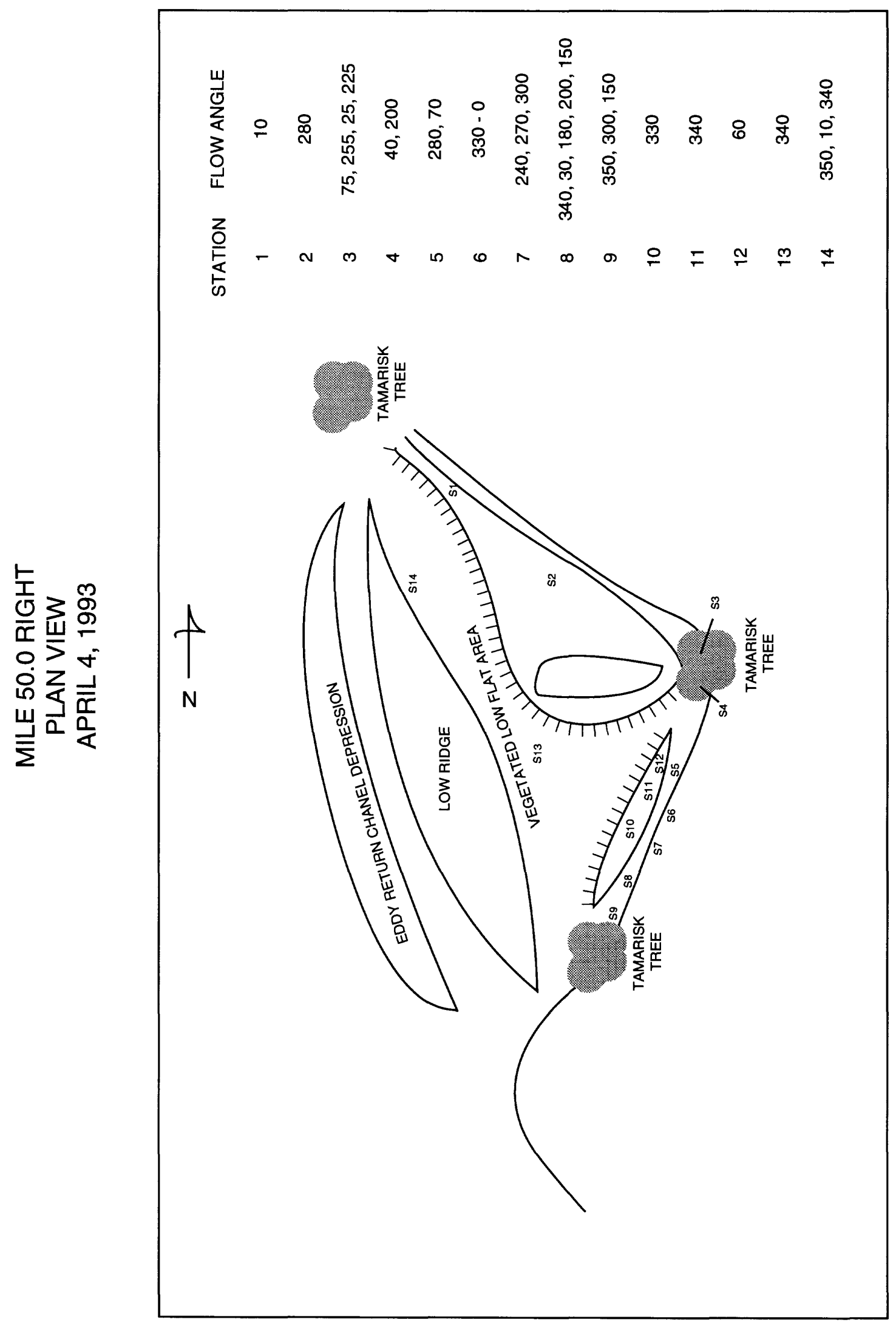


MILE 52 LEFT

TRENCHES $1-4$

MAY 15, 1991

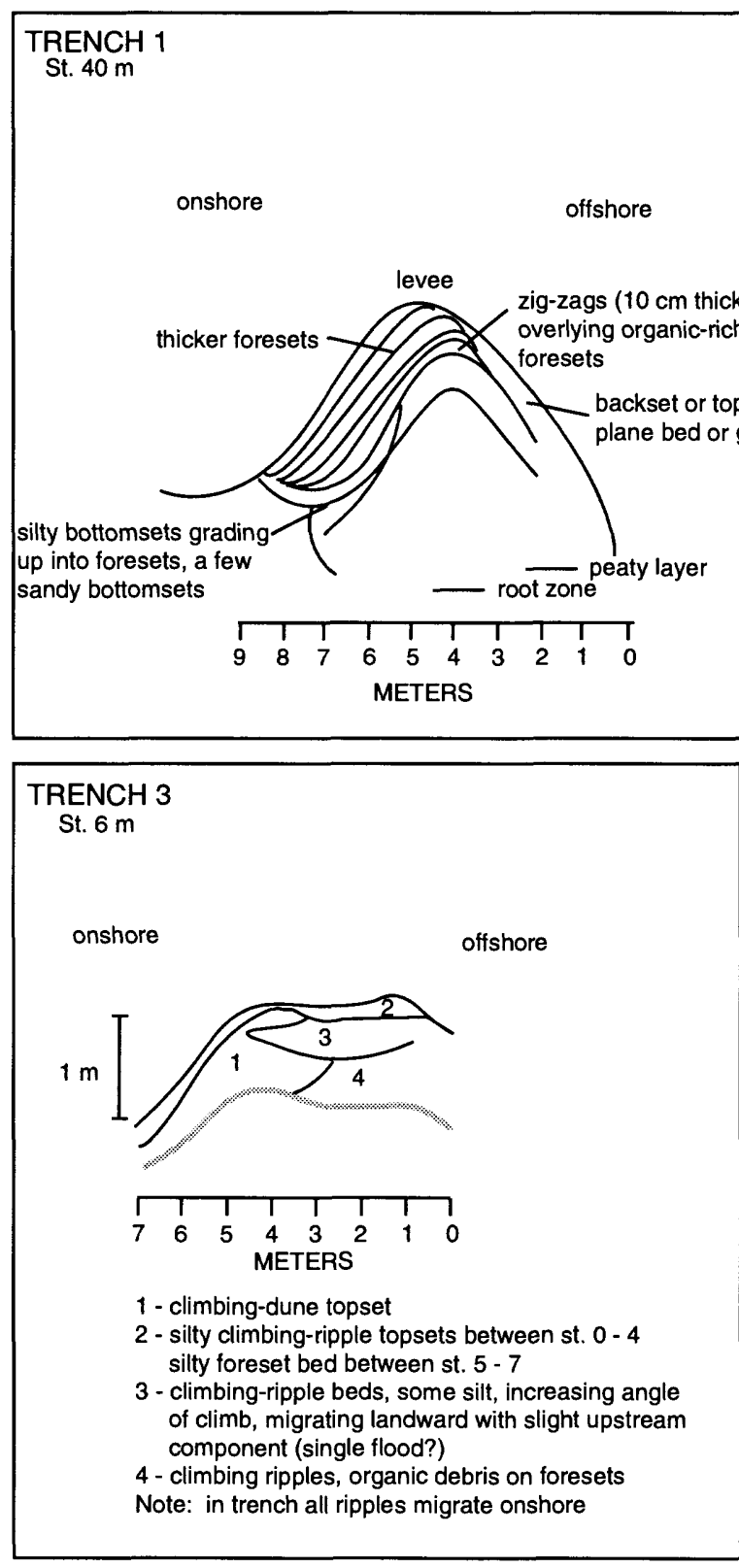

\section{TRENCH 4 \\ River Left (downstream)}

onshore offshore

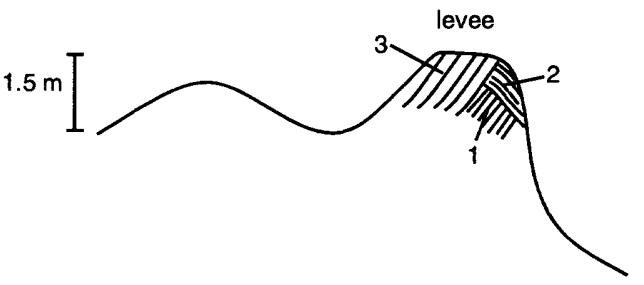

1 - avalanch beds dipping onshore, organic particles, lens-shaped in strike section, inverse grading dips -30 degrees

2 - steep ( 28 degrees) dips offshore, bedding indistinct, possible wave ripples at one horizon

3 - like unit 1, but no organic particles, not as planar in dip section

Note: levee parallel to bank 


\section{NANKOWEAP \\ MILE 53 RIGHT \\ TRENCH 1 \\ MAY 17, 1991}

\section{TRENCH 1}

OFFSHORE

ONSHORE

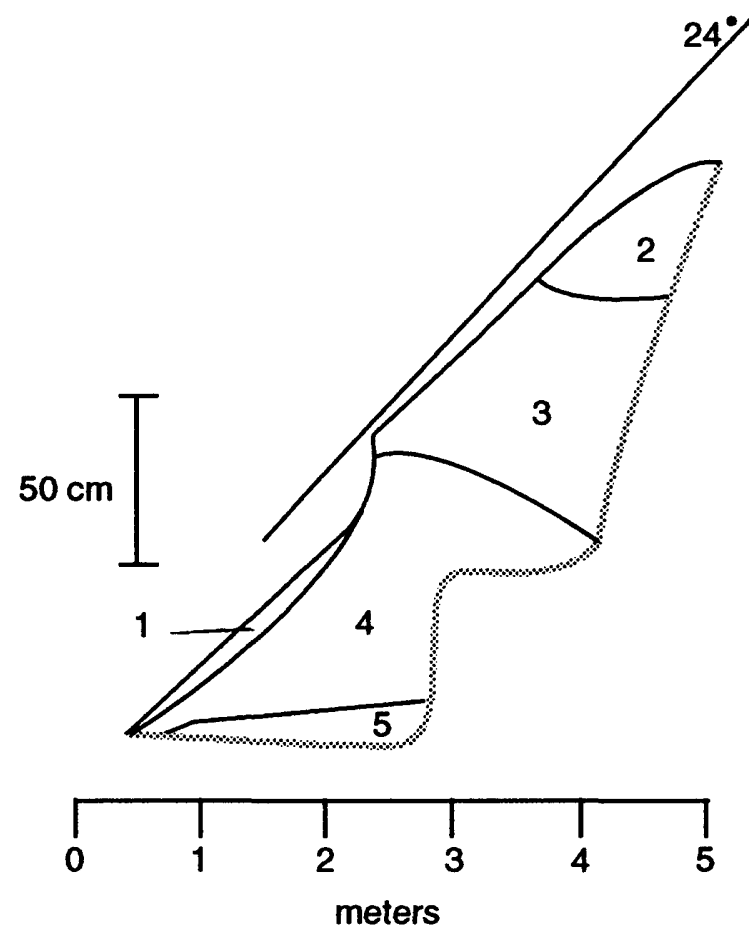

1 - muddy, sandy drape deposited by recent powerplant flows

2 - climbing wind ripples (post 1986)

3 - silty sand, upstream fluvial climbing-ripple beds; several deformational structures; possible wind ripple structures. Beds dip onshore.(1984 - 1986? floods)

4 - some salt-and-pepper sand as unit 5, cross-bedded, dipping mostly onshore, but with slight upstream component. Upper $5 \mathrm{~cm}$ are disturbed by roots. Contains buried trees that were at the surface in 1980 air photo. (1983 flood deposit?)

5 - relatively coarse-grained, clean, salt-and-pepper sand, very poorly laminated climbing ripples; bottomsets of unit 4, or gradually grade upward into unit 4. (1983 flood deposit?) 


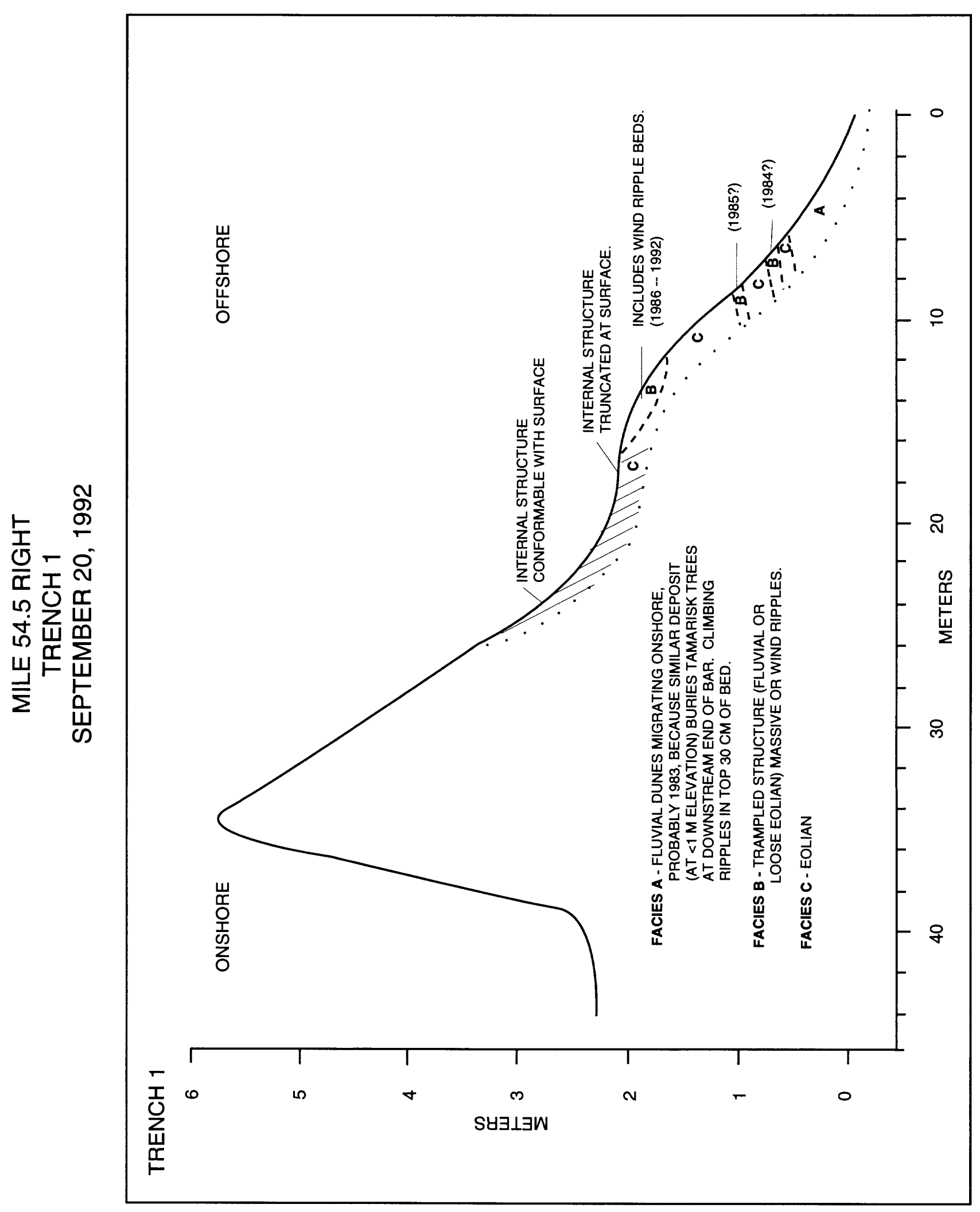



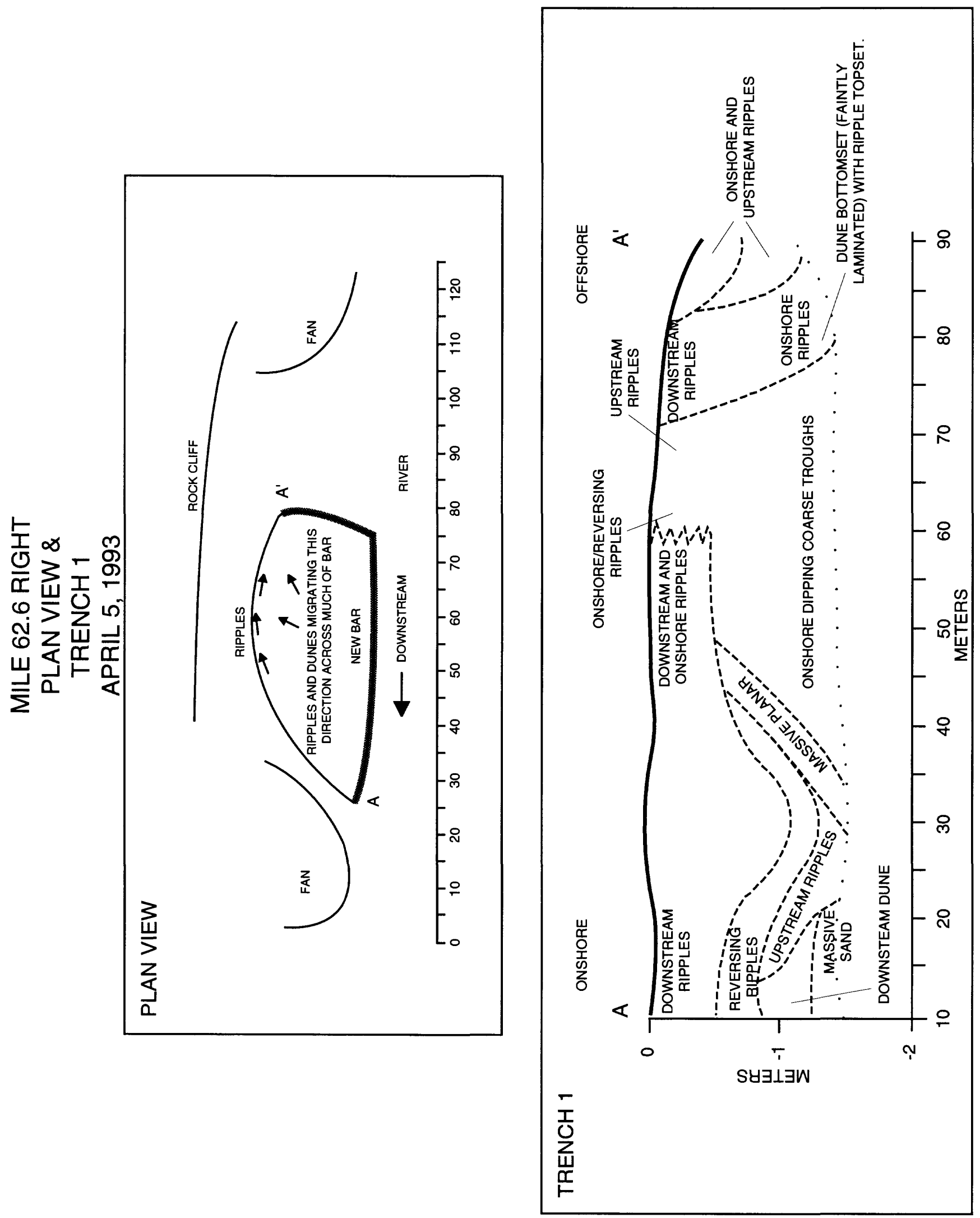


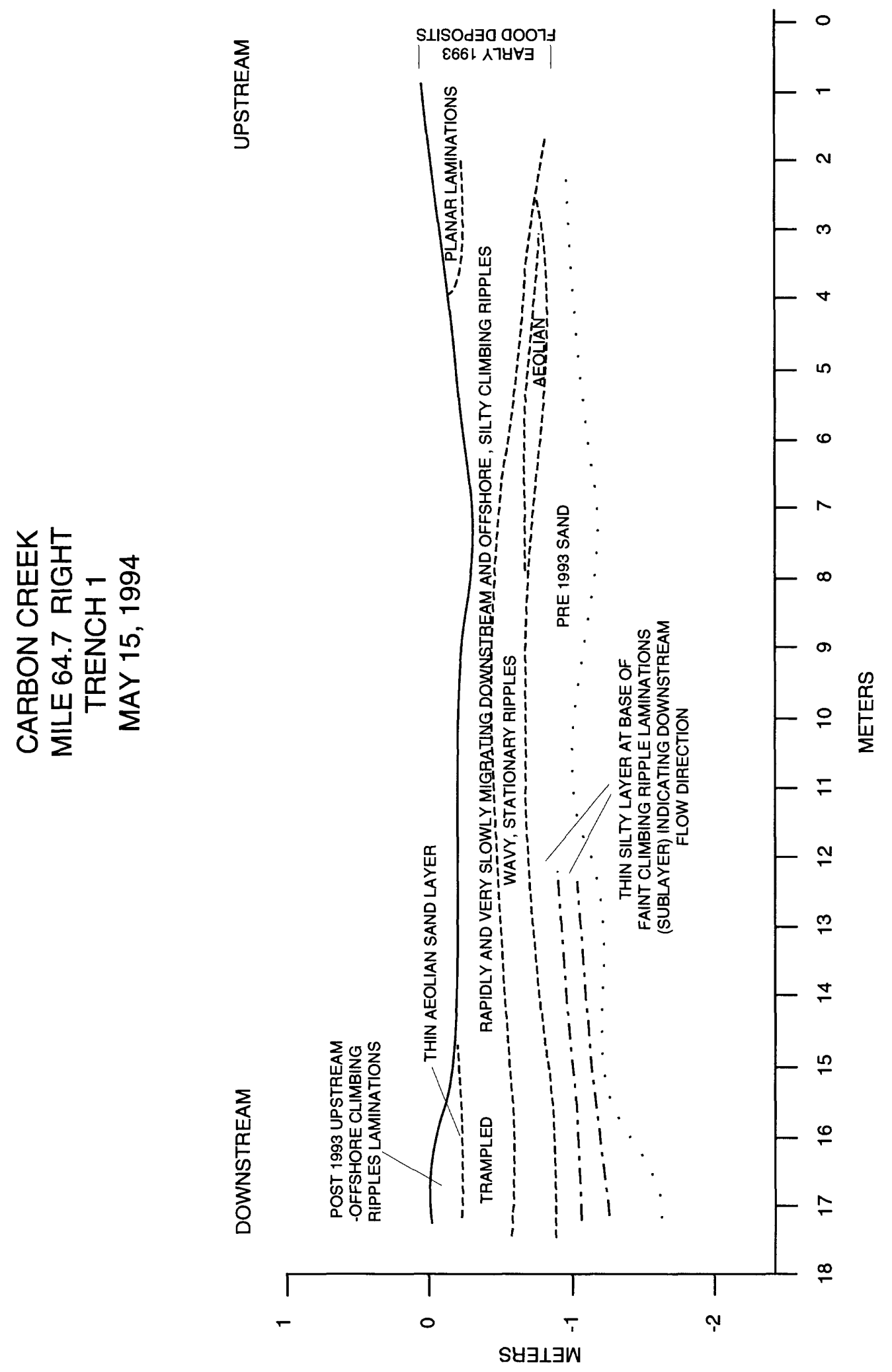




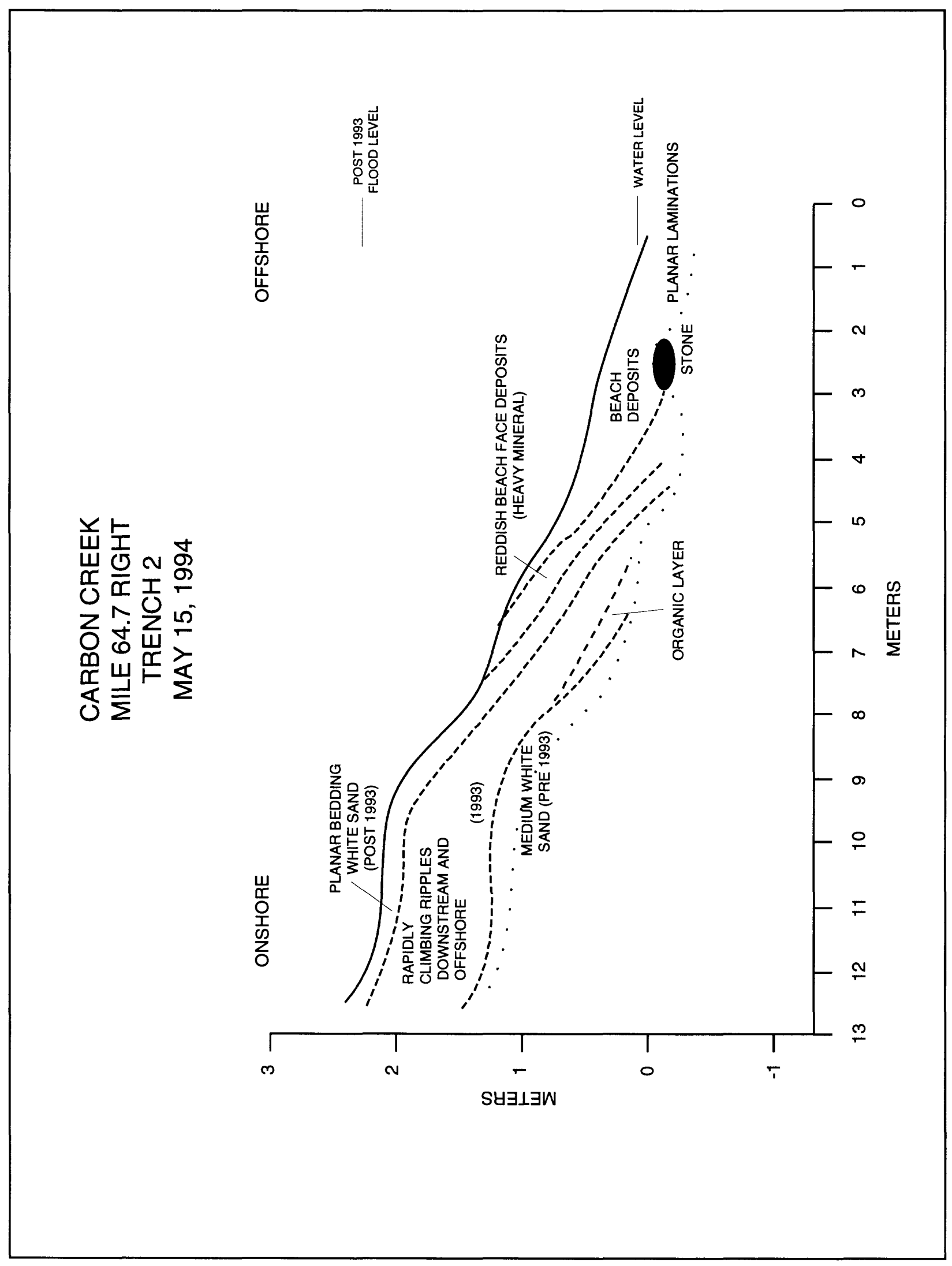




\section{PALISADES \\ MILE 65.6 LEFT \\ TRENCH 1 \\ OCTOBER, 1990}

\section{TRENCH 1}

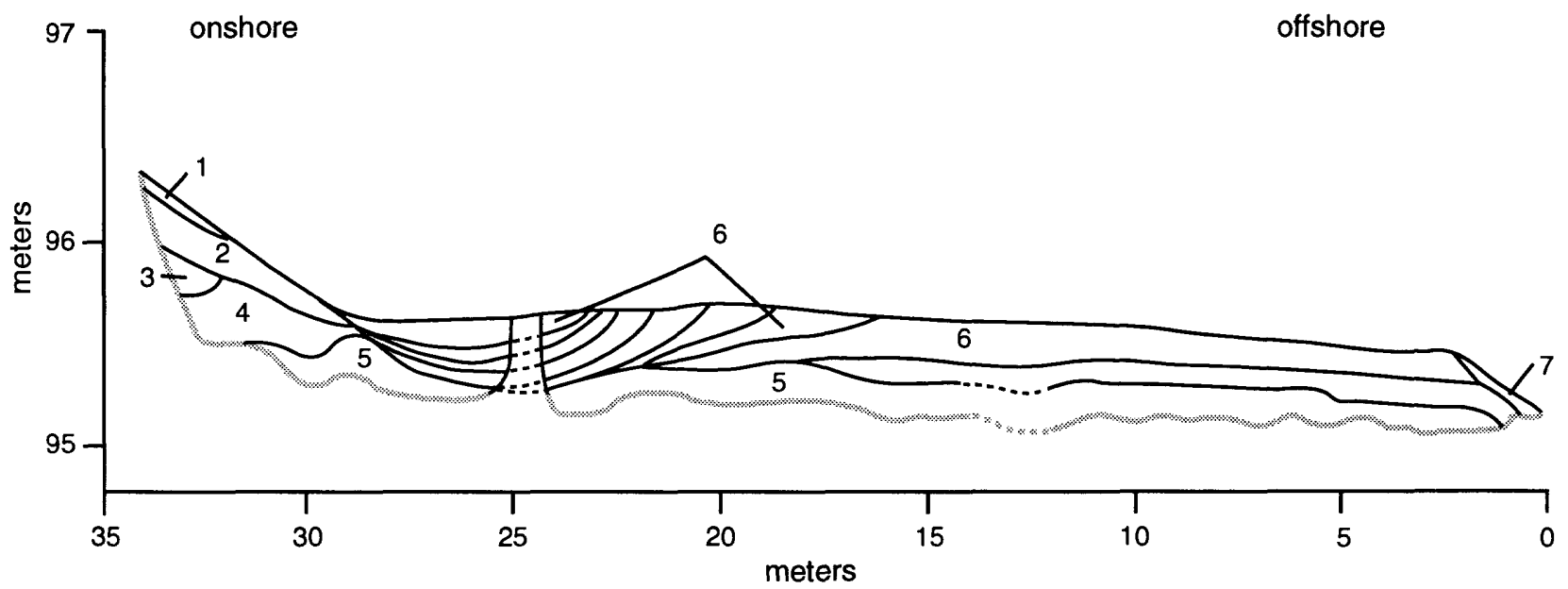

1 - clean sand, bubble structures, and climbing ripples

2 - sand and muddy sand, climbing-ripple structure: migration directions upstream and slightly offshore

3 - fluvial foresets dipping offshore

4 - foresets dipping onshore; some fluvial climbing-ripple bottonsets, a few of which are climbing vertically (photos)

5 - sand and muddy sand foresets dipping onshore; some organic-rich climbing-ripple structures on foresets migrating upstream

6 - climbing-ripple structures that build a trough from the offshore flank; ripple migration directions are mostly upstream

7 - beach swash bedding 


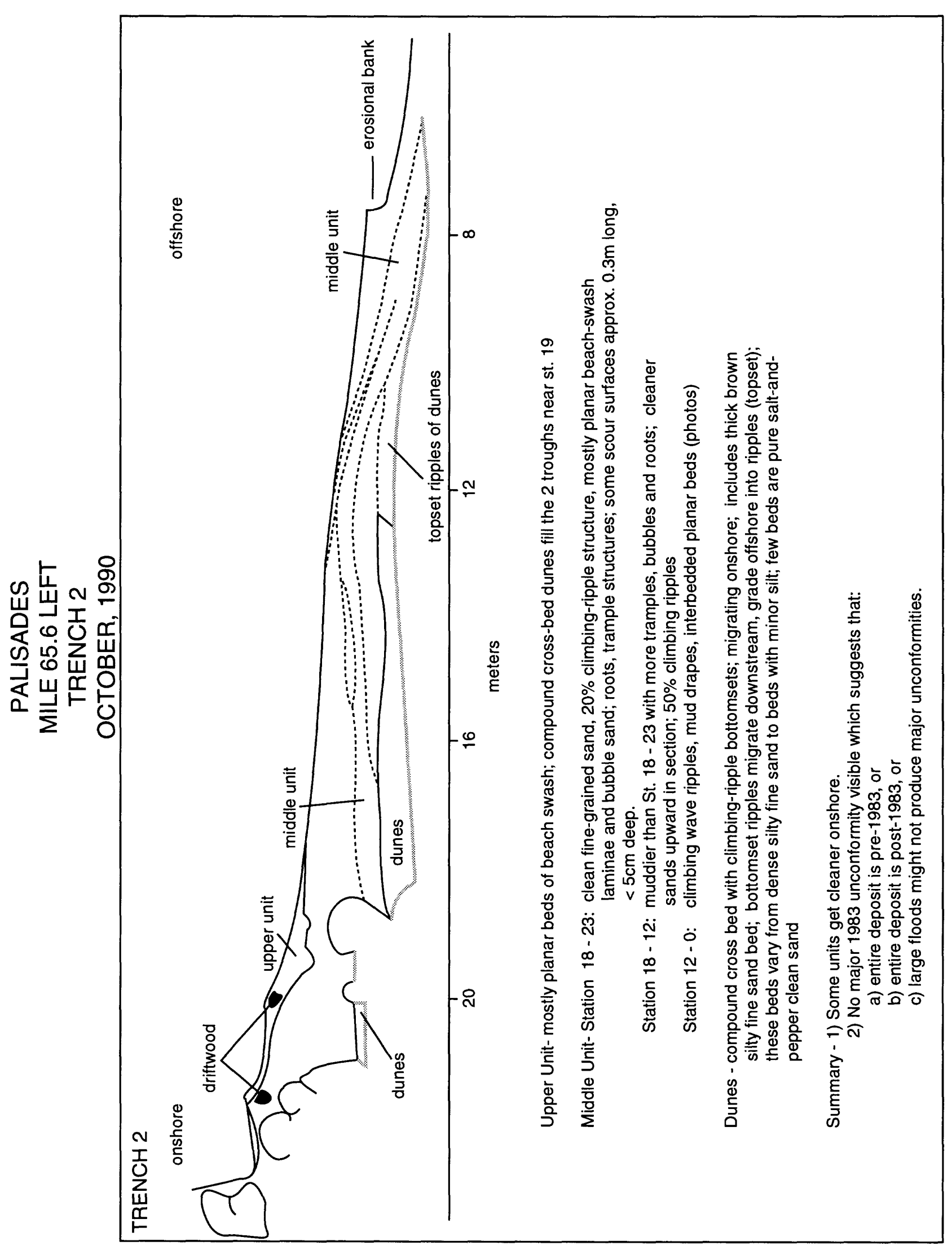


TANNER

MILE 68 RIGHT

TRENCHES $1 \& 2$

APRIL 6, 1993
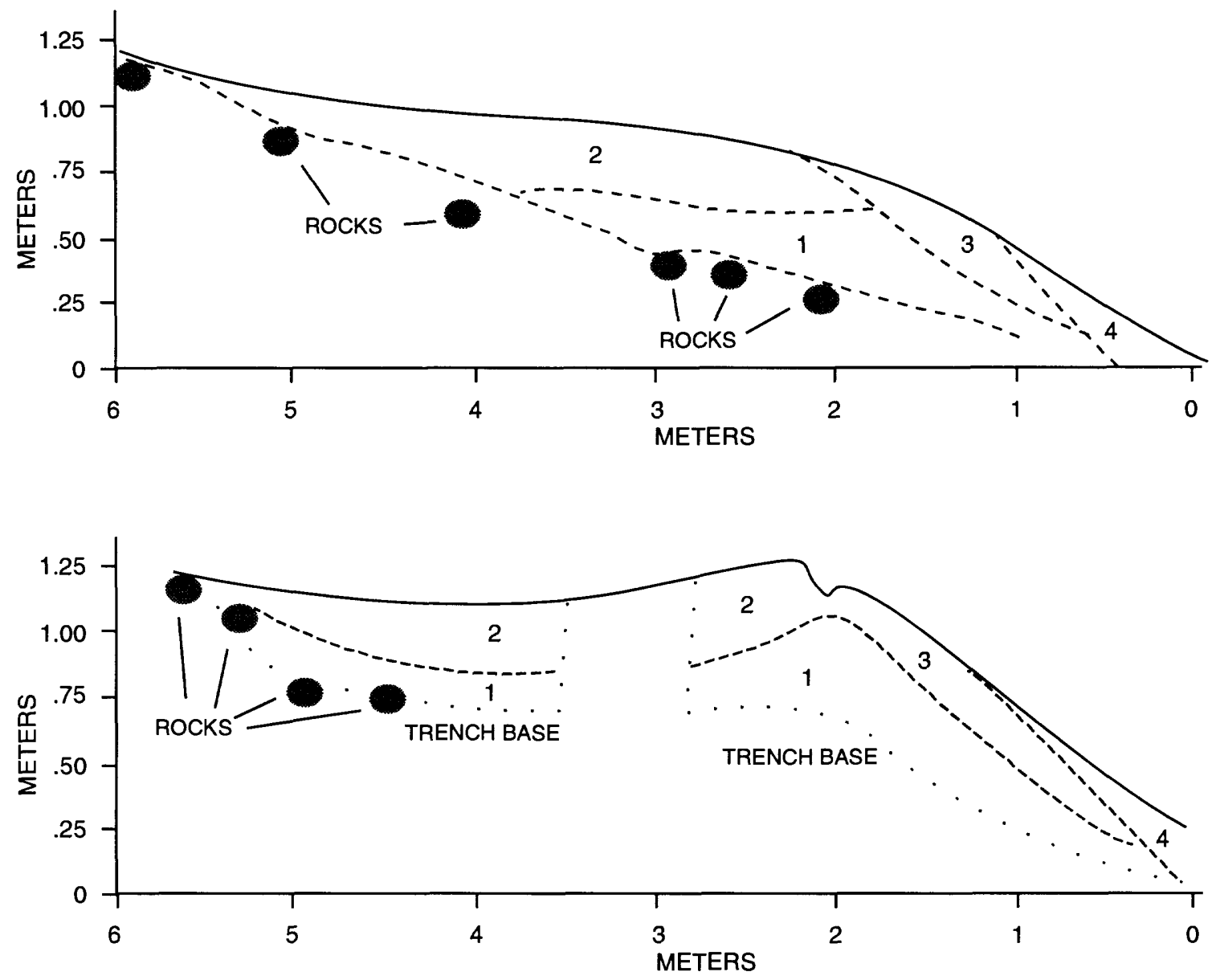

1 - PRE-1993, MUDDY CLIMBING RIPPLES, POSSIBLE HORIZONTAL LAMINATIONS, ORGANICS, AND ROOTLETS.

2 - JANUARY 1993 CLIMBING RIPPLES MIGRATING DOWNSTREAM AND OFFSHORE, ORGANIC FORESETS, SILTY.

3 - SUBSEQUENT 1993 FLOOD DEPOSITS, BEACH SWASH - WAVE RIPPLE

TRANSGRESSIONS/REGRESSIONS (AS MANY AS SIX).

4 - POST-FLOODS BEACH SWASH. 
GRAPEVINE

MILE 81 LEFT

SITE LOCATION,

TRENCH 1

APRIL 7, 1993

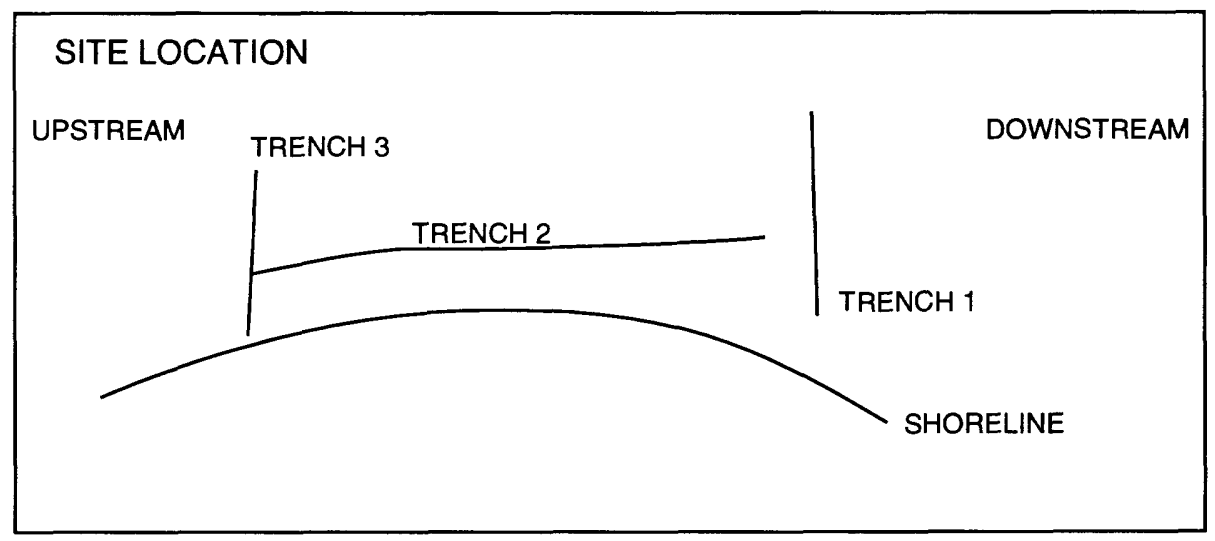

\section{TRENCH 1}

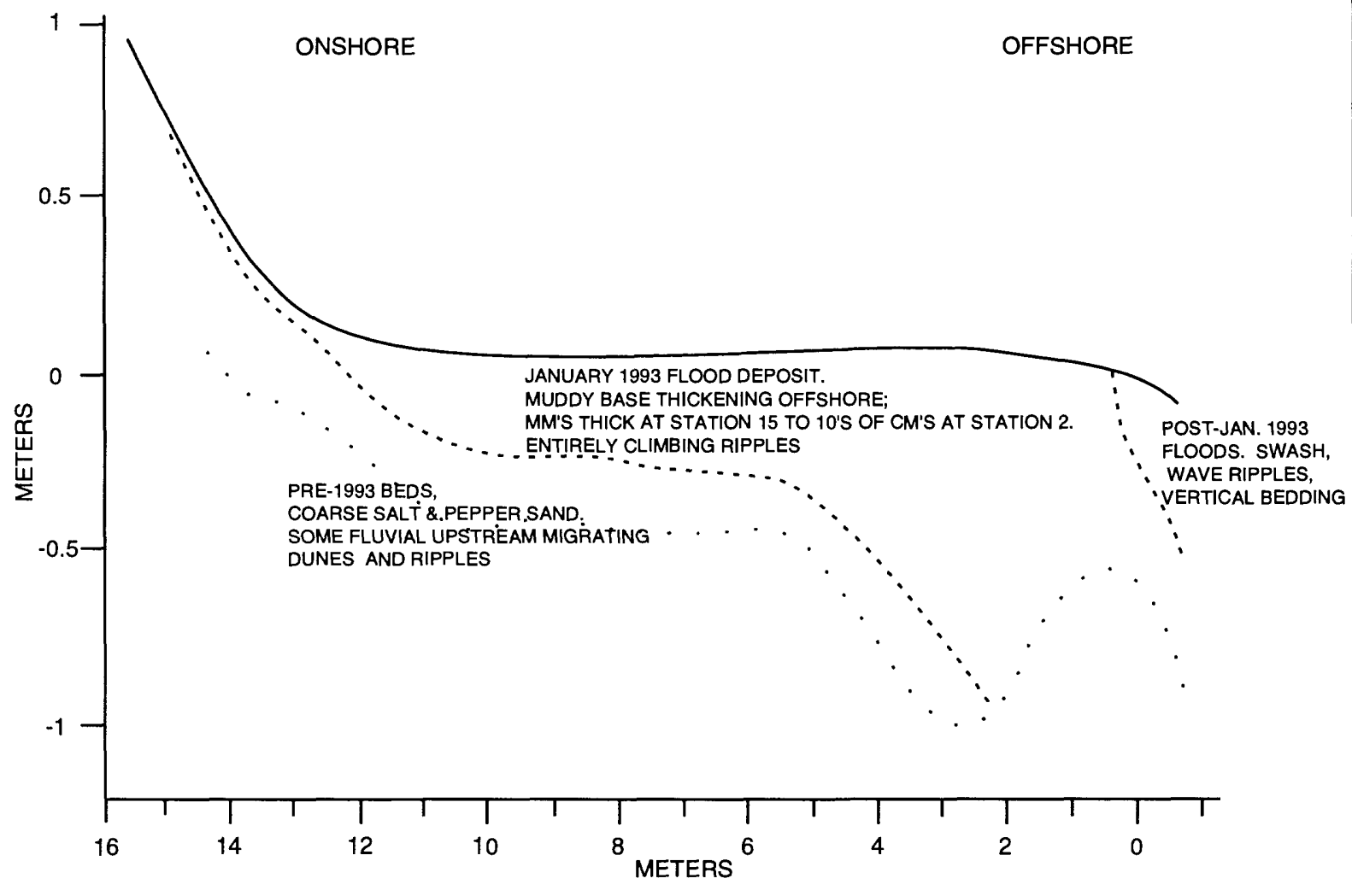




\section{GRAPEVINE}

MILE 81 LEFT

TRENCH 2 \& 3

APRIL 7, 1993
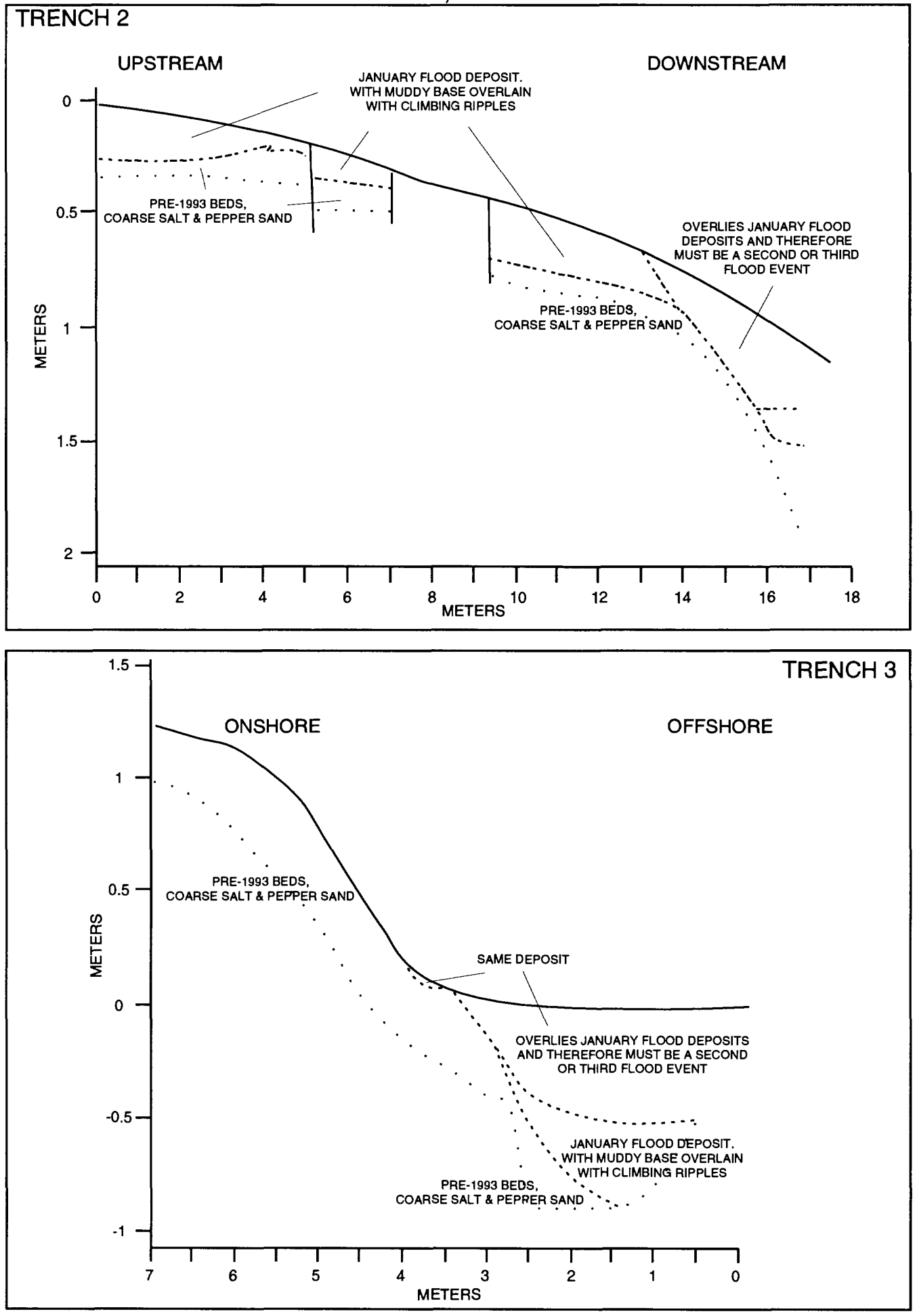


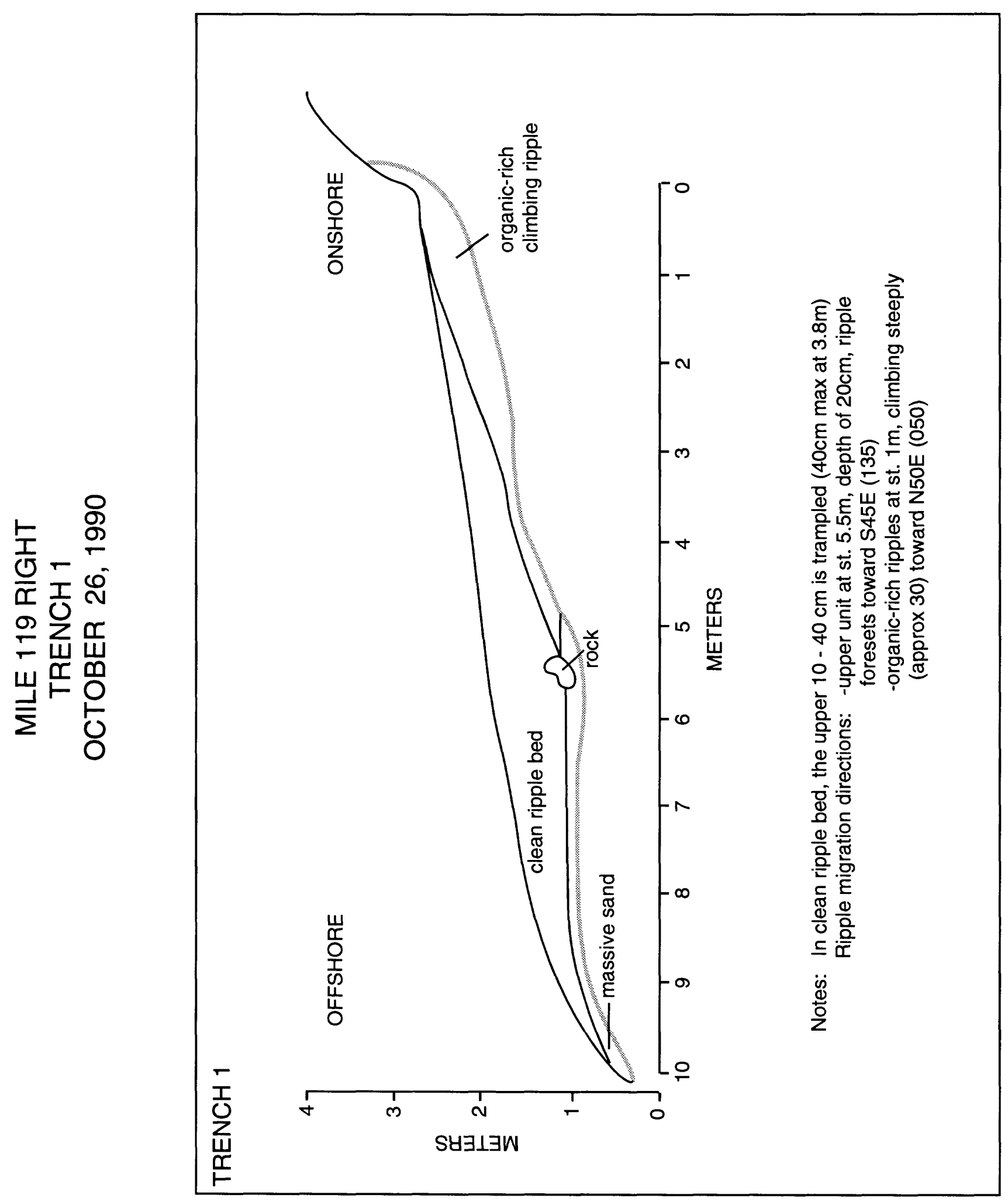




\section{TRENCH 2}

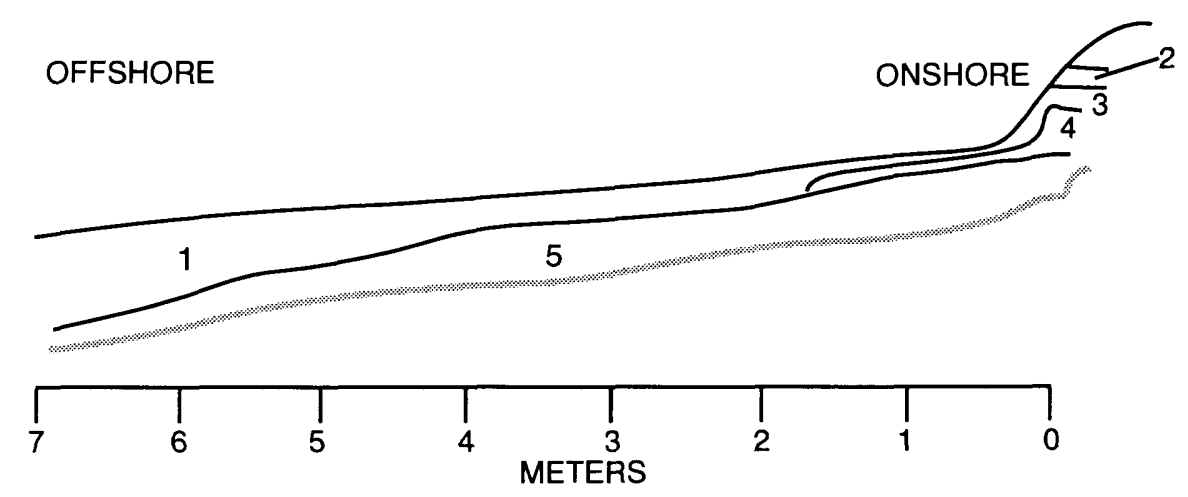

1 - muddy rippled sand with trample structures; possible thin eolian beds

2 - clean ripple-bedded sand, same unit as clean rippled sand in trench \#1 (1984 - 1986 high flows)

3 - planar-bedded clean sand; probably 1983

4 - dunes migrating downstream and massive bedding (photo) in same bed

- at $0.4 \mathrm{~m}$ mark, dune-scale cross-bedding toward N75E (075 degrees)

5 - 1983 massive sand (same as in trench 1)

\section{TRENCH 3}

\section{OFFSHORE ONSHORE}
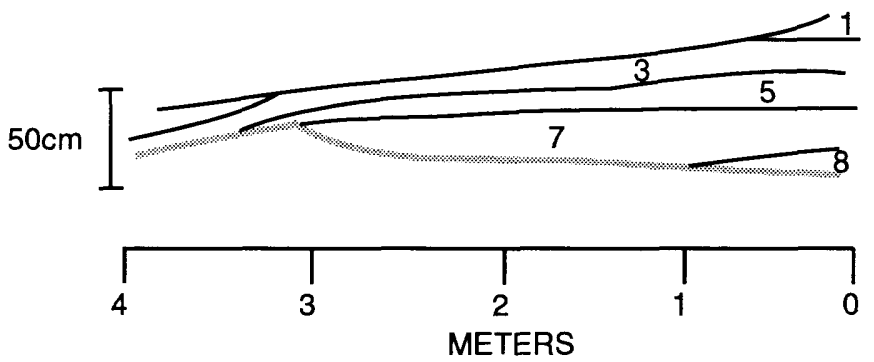

1 - diverging ripple migration direction indicates that the reattachment point is here; bed is muddier here also (photos)

7 - trampled, massive, pin-striped eolian, and two beds of wave ripples

Plan view of trenches $3,4, \& 5$ Station 0 of trench 3,4 , and trench 5 are the same location.

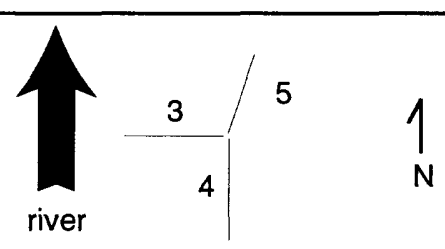




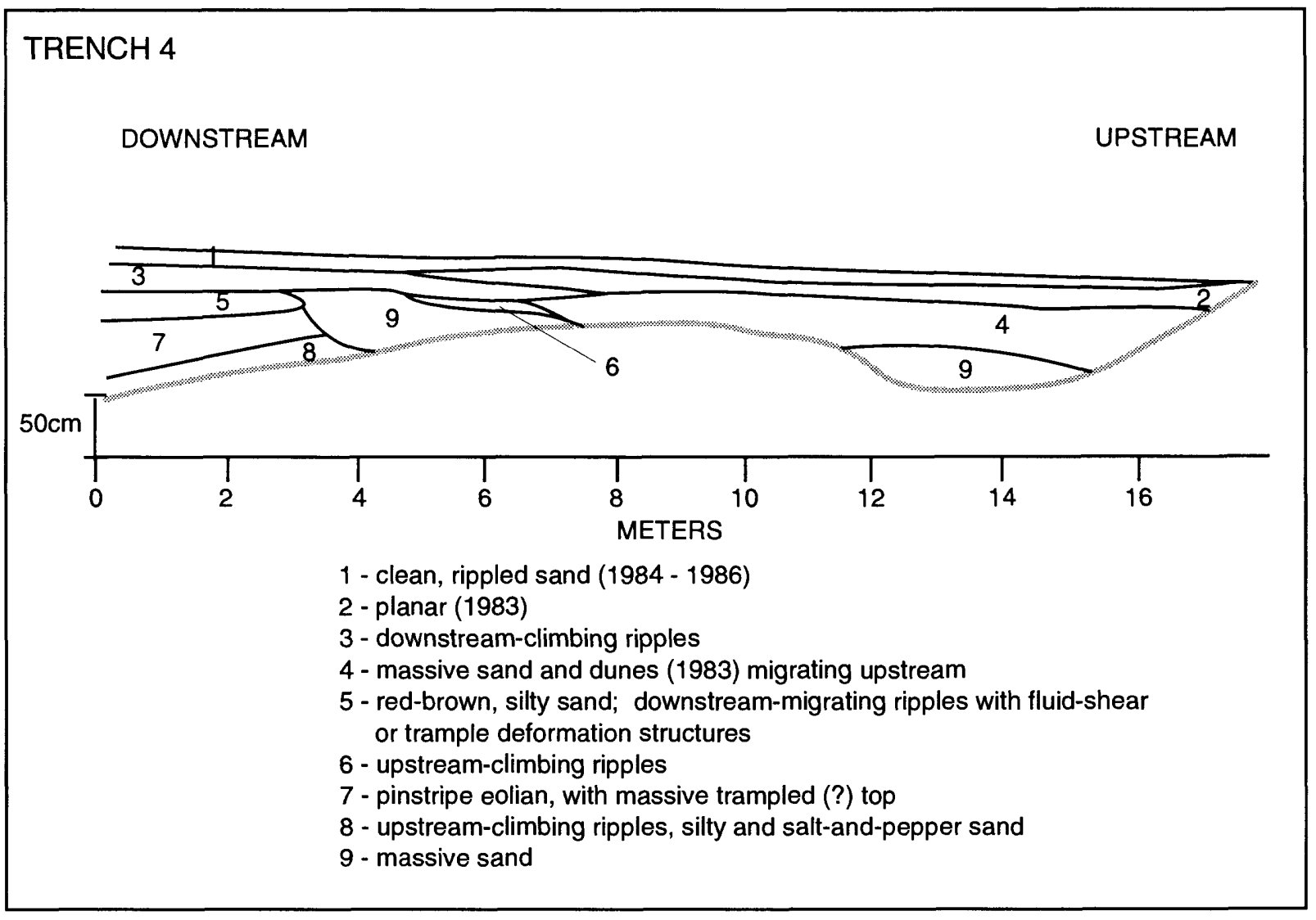

TRENCH 5

DOWNSTREAM

UPSTREAM
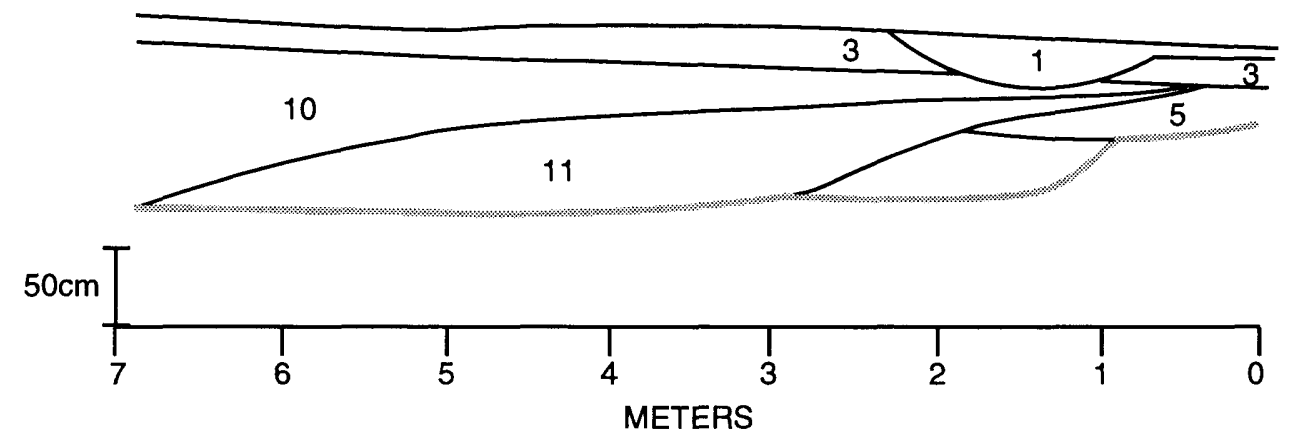

1 - clean, rippled sand

3 - salt-and-pepper sand, dunes migrating downstream

5 - muddy climbing ripples with scarp in trench 4

10-fine sand climbing ripples migrating downstream

11-alternating sand and muddy beds dipping downstream 


\section{MILE 119.5 RIGHT \\ TRENCHES 1-4 \\ MAY 19, 1991}

\section{TRENCH LOCATION PROFILE}

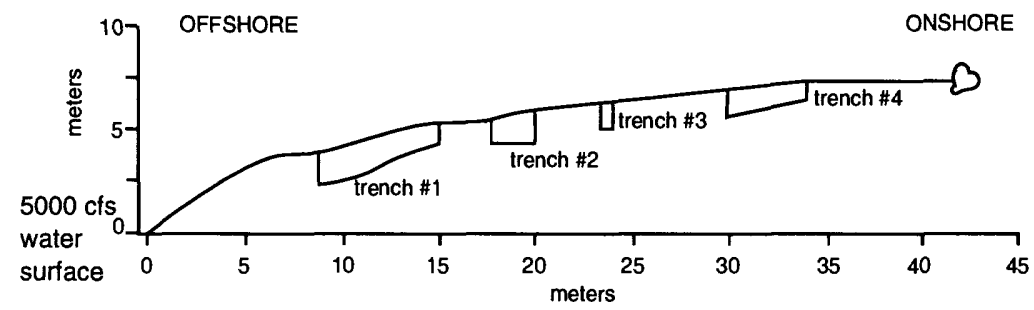

\section{TRENCH 1}

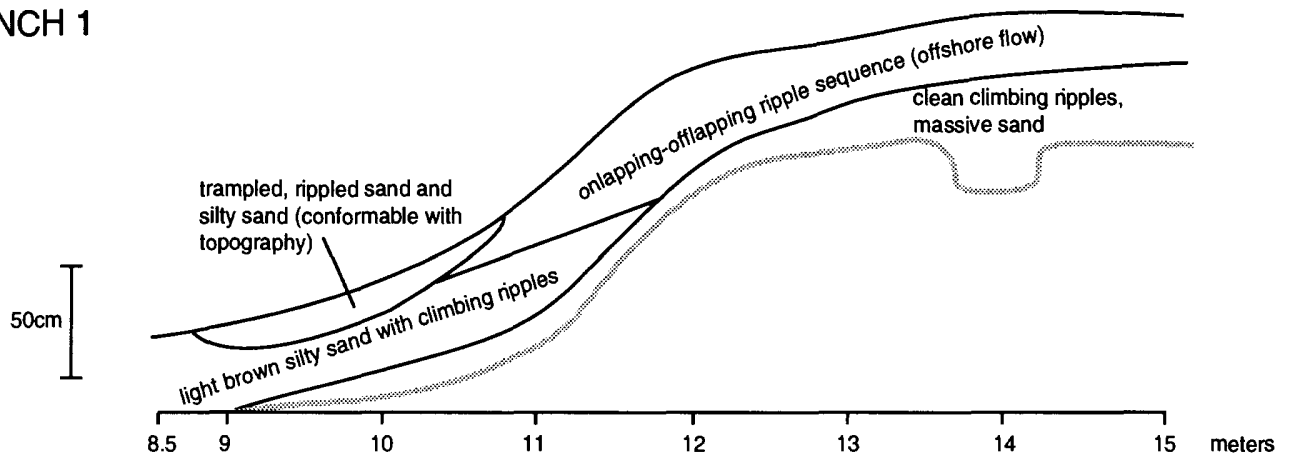

\section{TRENCH 2}
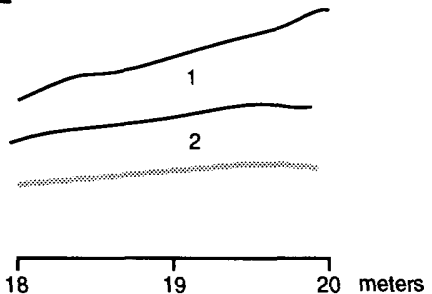

1 - interbedded, sand, silty sand, trample structures, overlain by fluvial muds, then trampled sands; transition zone in elevation from powerplant to ' 84 , ' 85 \& ' 86 floods; at st. 19 muddy bed pinches out, thickening offshore (may be peak powerplant discharge)

2 - clean sand, possible fluvial climbing ripples, charcoal bits; other possibility is eolian; bounding surfaces dip upstream and onshore

\section{TRENCH 3}

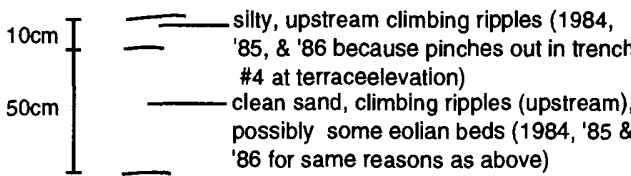

TRENCH 4

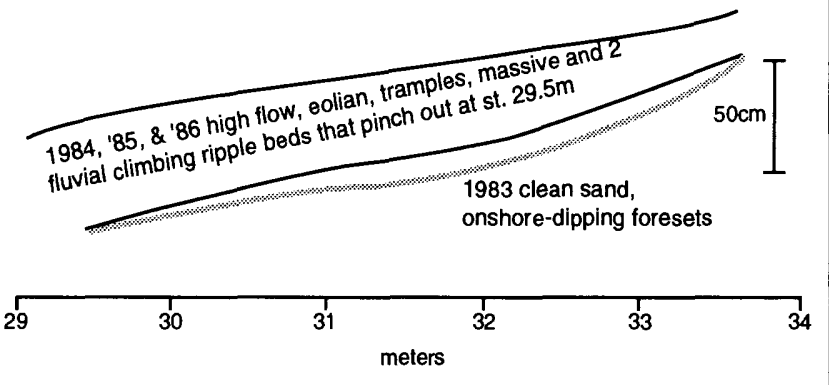


MILE 119.5 RIGHT

TRENCHES 5 \& 6

MAY 19, 1991

TRENCH 5

downstream

upstream

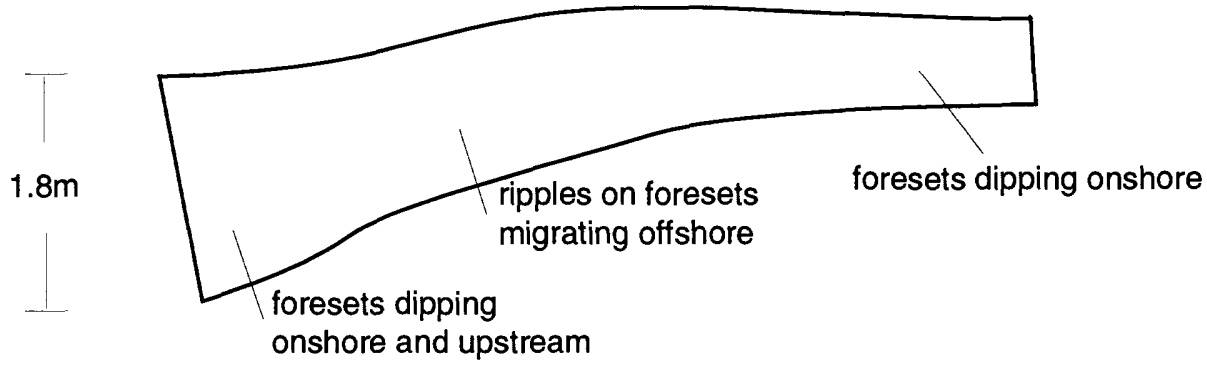

TRENCH 6

OFFSHORE
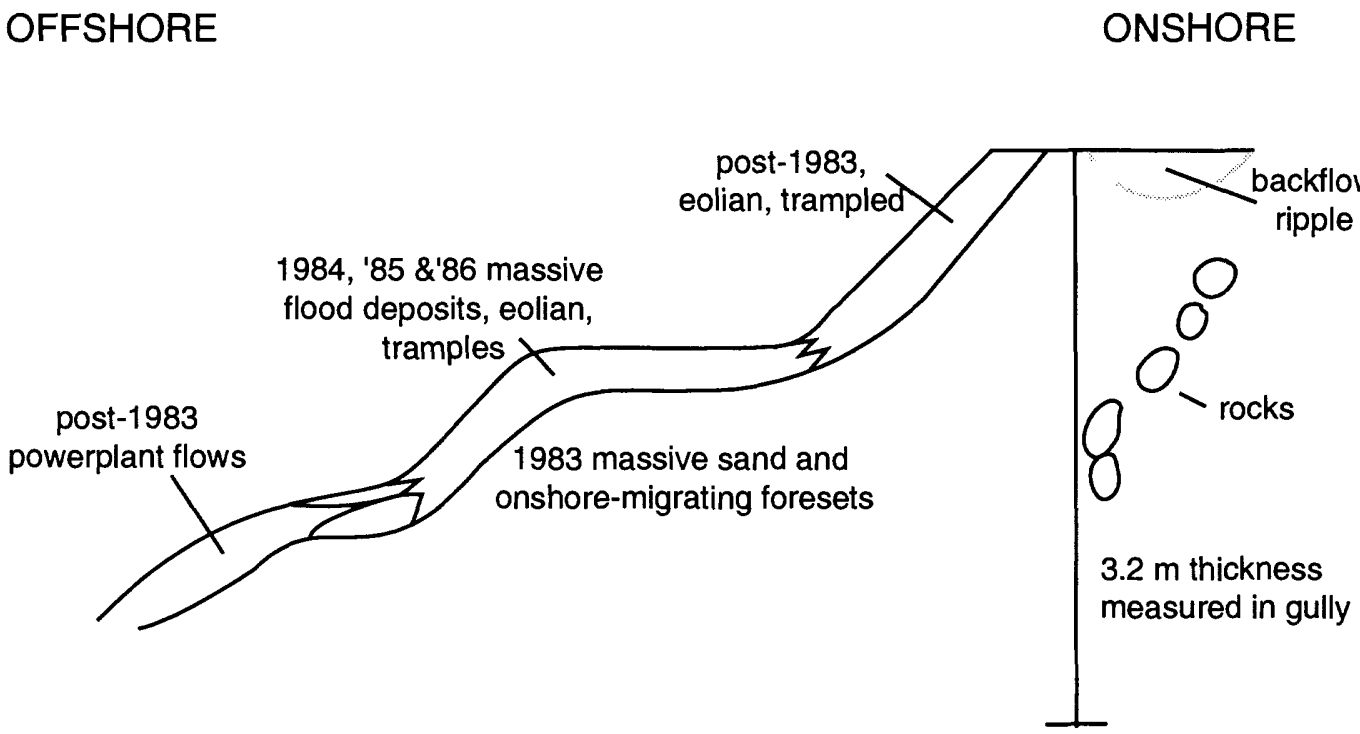


\section{MILE 122 RIGHT \\ TRENCH 1 \\ MAY 23, 1991}

\section{TRENCH 1}

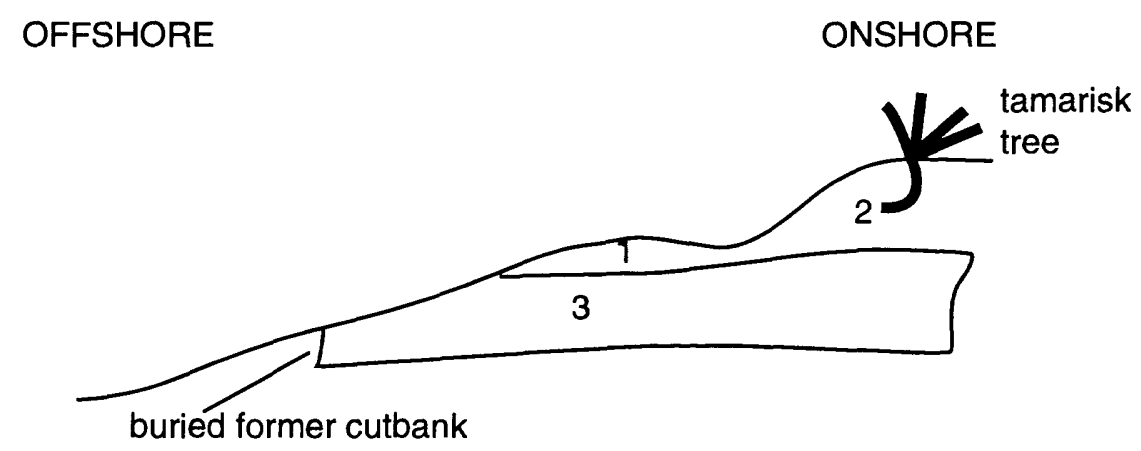

1 - mostly pre-dam silts and sands

2 - 1983? dunes and climbing ripples

3 - massive sand and clean fluvial dune sand, below silty beds

- pre-dam, because tam roots in silty beds, but no tamarisk are at surface (or anywhere within tens of $m$ )

Note: tamarisk rooted in 1983 and sprouted shoots in 1984 - '85 


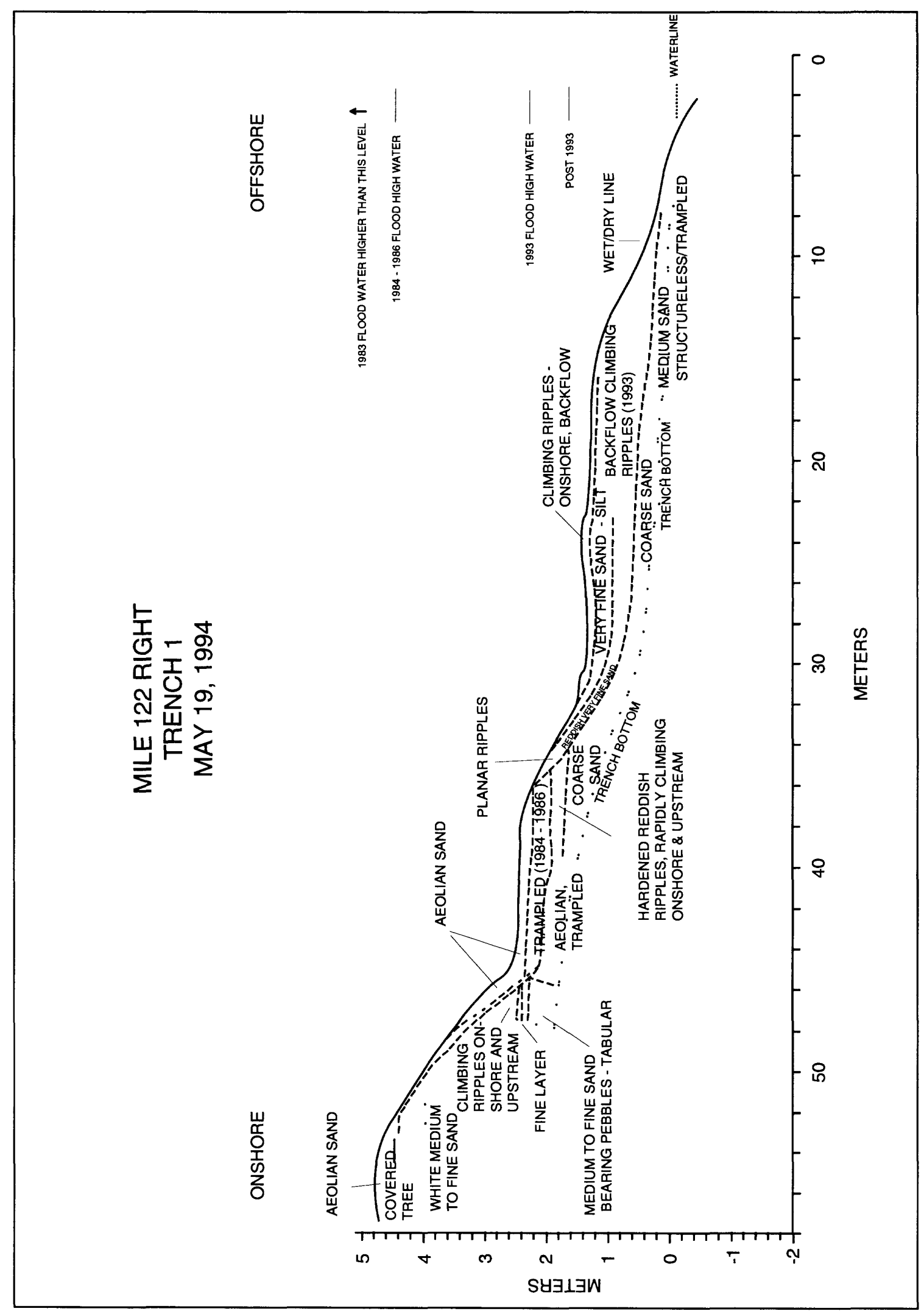




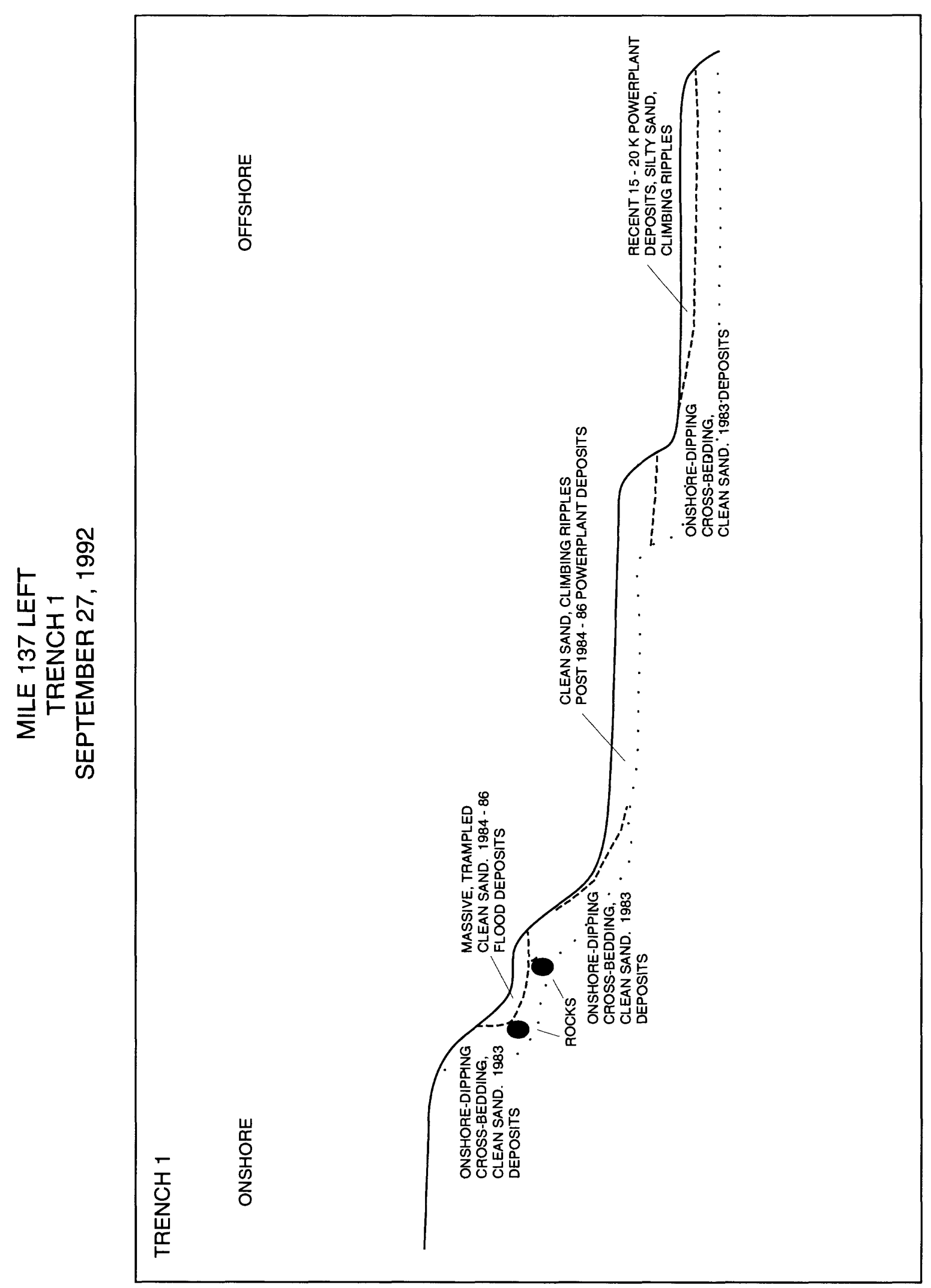




\section{FERN GLEN \\ MILE 168 RIGHT \\ PITS 1 - 3 \\ MAY 27, 1991}

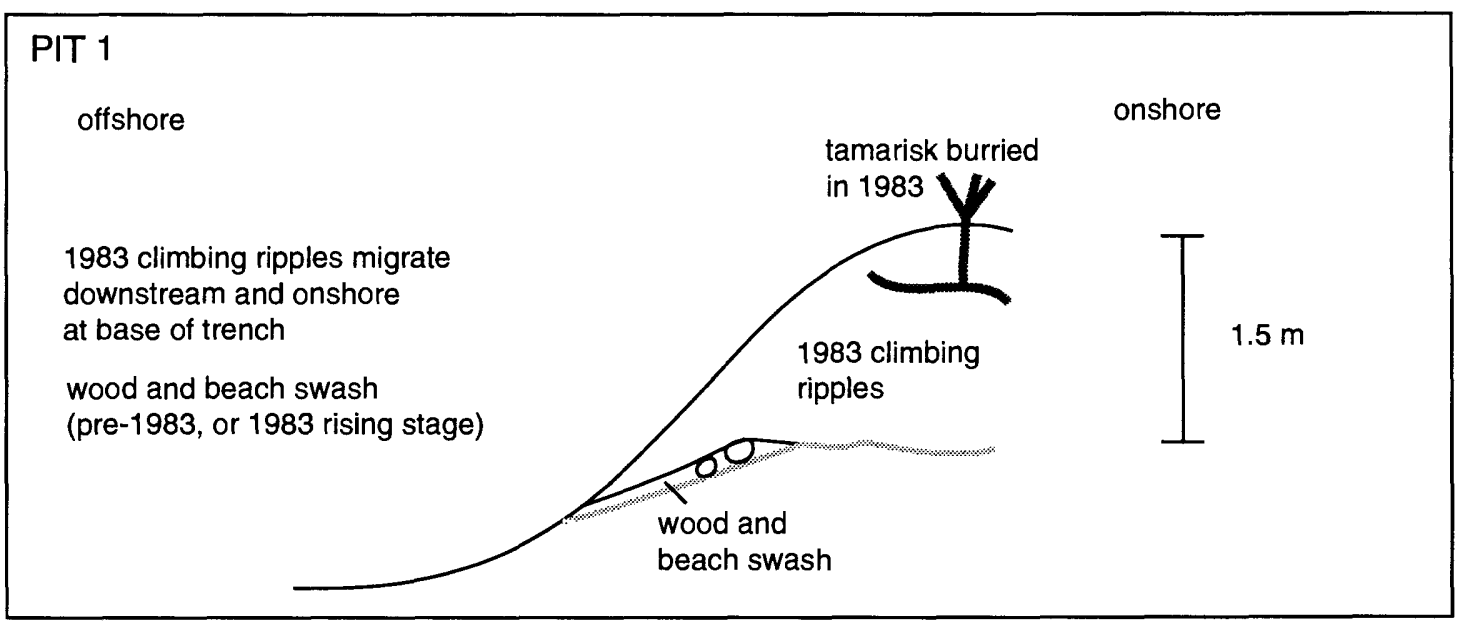

PIT 2

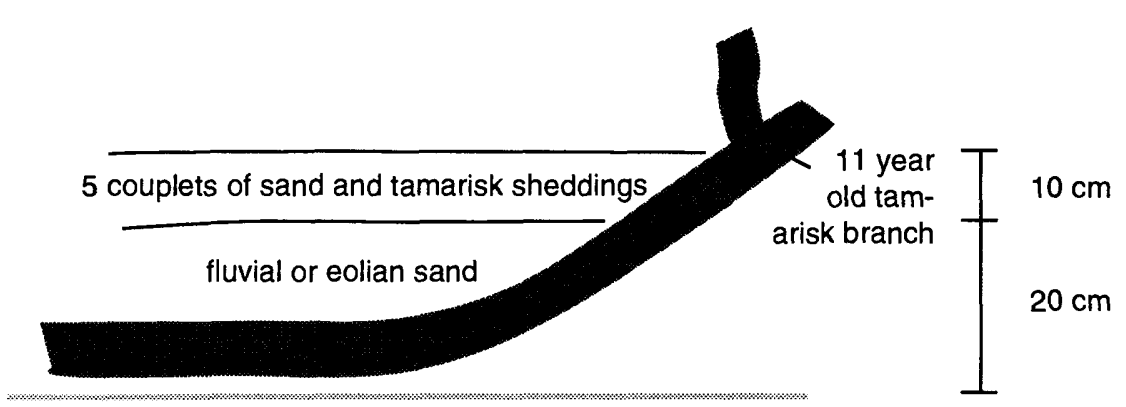

PIT 3

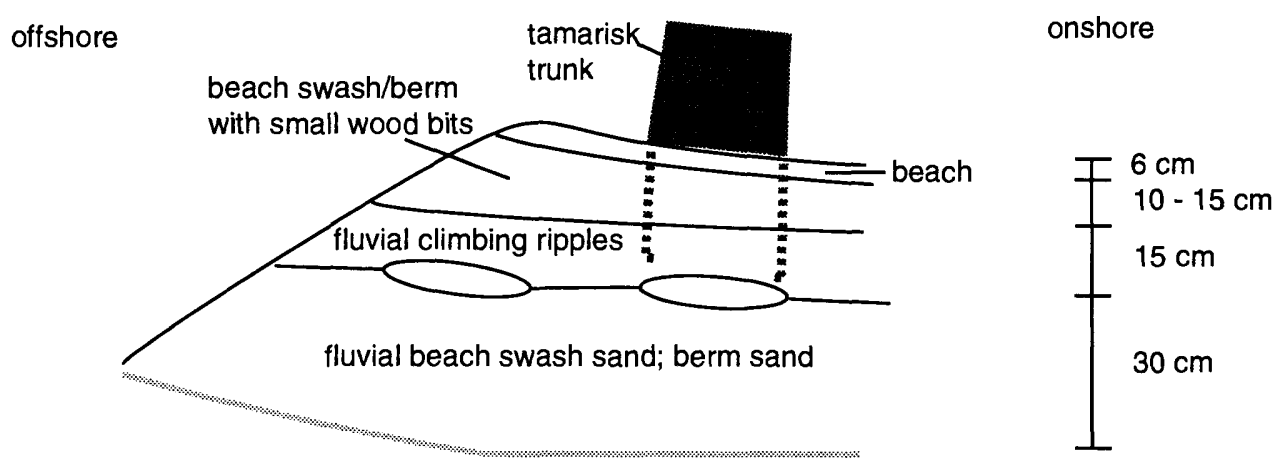

Large stones on surface $(15 \mathrm{~cm}$ diameter).

Maximum 1983 flood deposit is from stones up. (i.e. $36 \mathrm{~cm}$ ) 


\section{FERN GLEN}

MILE 168 RIGHT

TRENCH 1

MAY 28, 1991

\section{TRENCH 1}

offshore

onshore

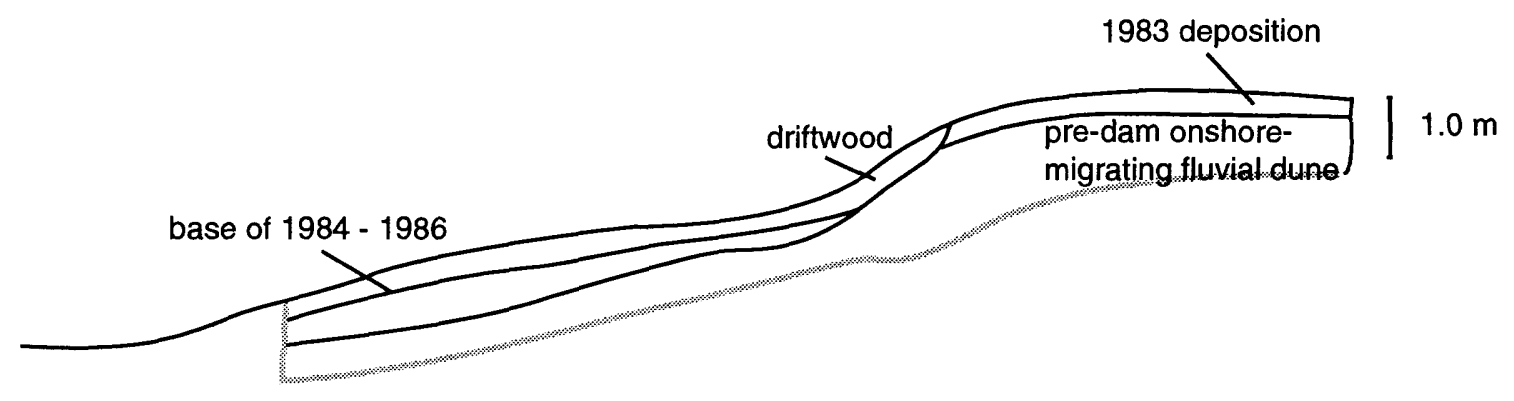

Note: Maximum 1983 deposition is $42 \mathrm{~cm}$.

Same stratigraphic section as in Pit 2 


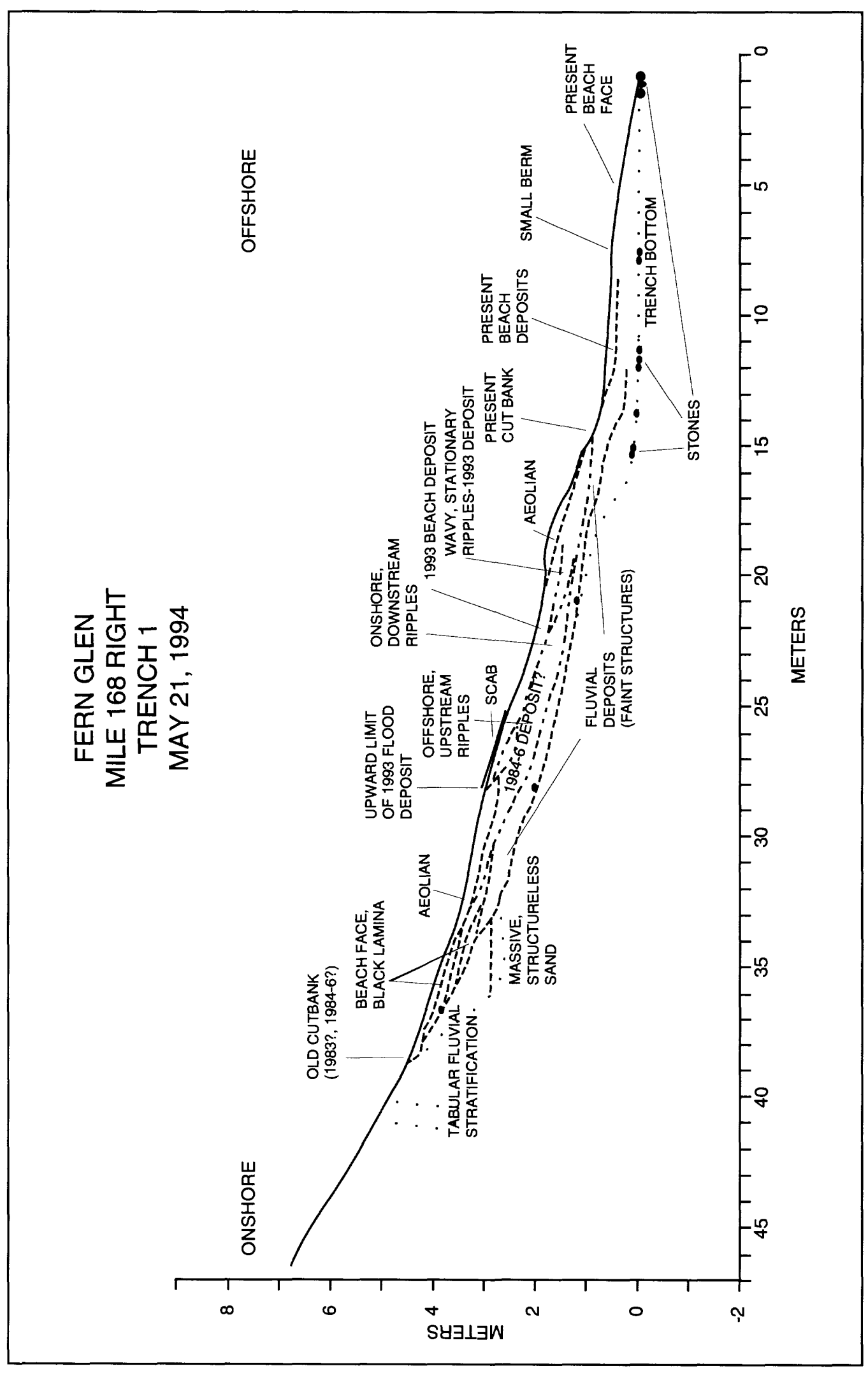




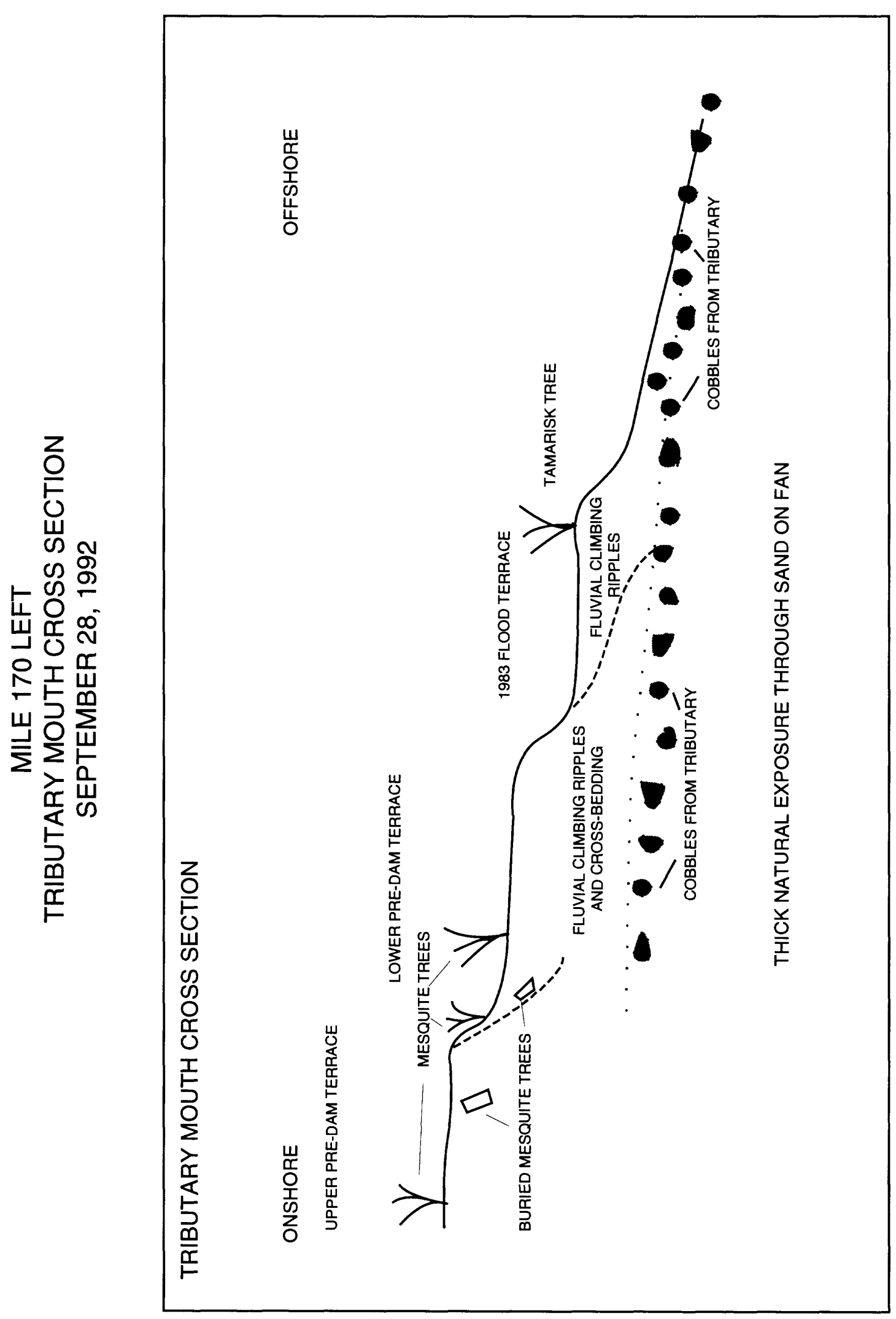




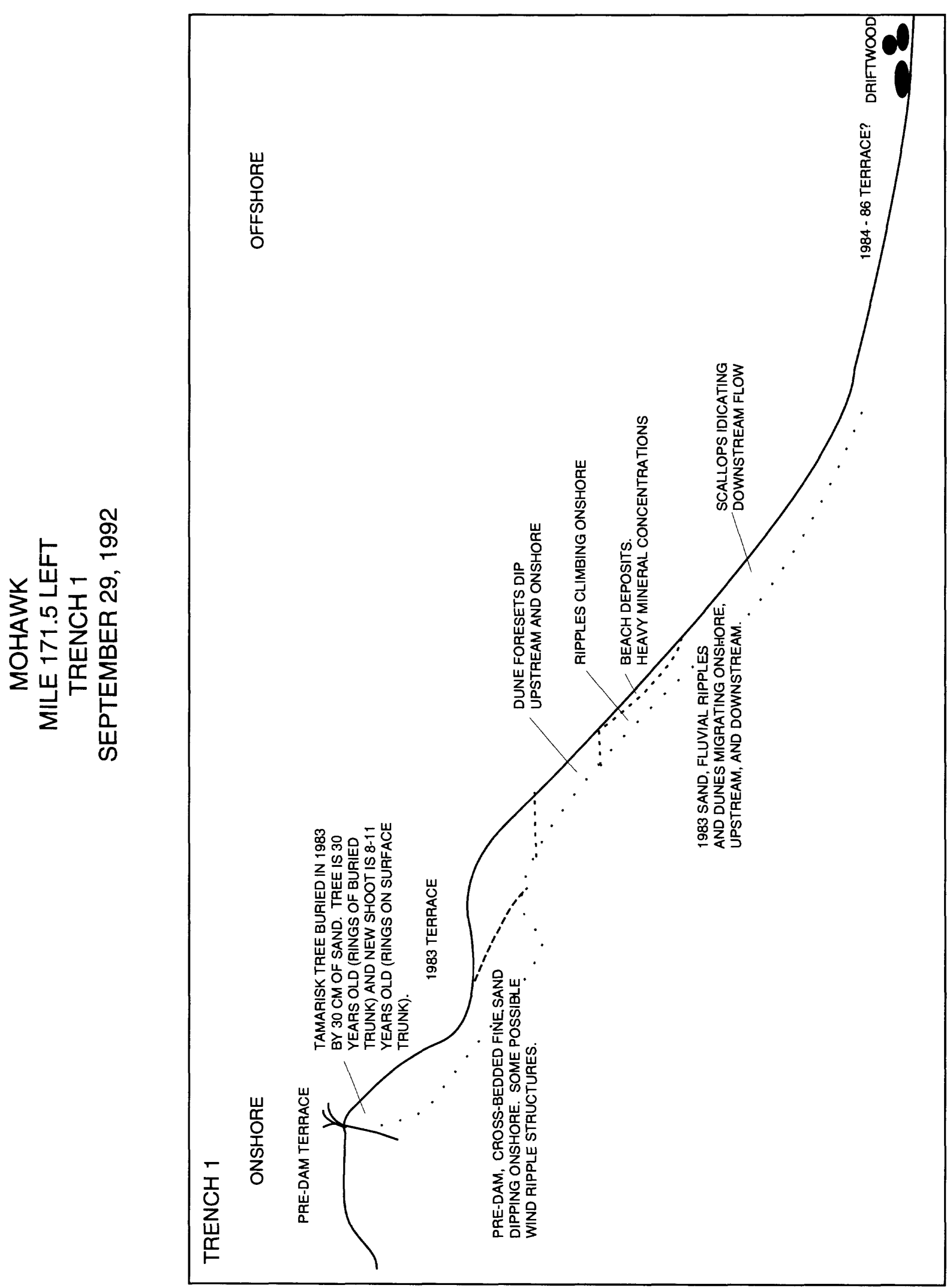

